Brazilian Journal

of Chemical

Engineering

\title{
POTENTIAL OF AUTOCHTHONOUS SULFATE-REDUCING MICROBIAL COMMUNITIES FOR TREATING ACID MINE DRAINAGE IN A BENCH-SCALE SULFIDOGENIC REACTOR
}

\author{
Alessandra Giordani ${ }^{1}$, Elize A. Hayashi ${ }^{1}$, Renata P. Rodriguez ${ }^{1}$, \\ Leonardo H. S. Damasceno ${ }^{1}$, Heliana Azevedo ${ }^{2}$ and Gunther Brucha ${ }^{1 *}$ \\ ${ }^{1}$ Universidade Federal de Alfenas, Instituto de Ciência e Tecnologia, Laboratório de Microbiologia, Poços de Caldas, MG, Brasil. \\ ORCID - 0000-0002-6526-9129; ORCID: 0000-0003-0161-2124; ORCID: 0000-0002-2837-3437; ORCID: 0000-0002-6556-2552; \\ E-mail: gunther.brucha@unifal-mg.edu.br - ORCID: 0000-0002-0768-5773 \\ ${ }^{2}$ Comissão Nacional de Energia Nuclear, Poços de Caldas, MG, Brasil. ORCID: 0000-0001-8470-255X
}

(Submitted: December 30, 2017 ; Revised: December 5, 2018 ; Accepted: December 9, 2018)

\begin{abstract}
Biological acid mine drainage treatment depends significantly on inoculum origin, $\mathrm{pH}, \mathrm{COD} / \mathrm{sulfate}$ ratio, and carbon source. In this study, the performance and microbial diversity of anaerobic batch reactors used for sulfate reduction was evaluated. A medium $\mathrm{COD} /$ sulfate ratio of $1.14 \pm 0.10$ was used, and the evaluation was performed in two steps: Phase 1, based on the inoculum source (autochthonous, AUT, and non-autochthonous, N-AUT); and Phase 2, based on the carbon source (lactate, ethanol, and formate) and low pH. In Phase 1, the sulfate removal using both AUT and N-AUT biomasses were similar, 53\% and 59\%, respectively. In Phase 2, ethanol and lactate as electron donors yielded similar sulfate removal efficiencies of $42 \%$ and $44 \%$, respectively, at neutral $\mathrm{pH}$. When the initial $\mathrm{pH}$ was reduced from 4 to 3 , sulfate removal using formate remained nearly constant at $34 \%$, whereas it reduced from $43 \%$ to $30 \%$ with lactate, and dropped significantly from $18 \%$ to $7 \%$ with ethanol. Denaturing gradient gel electrophoresis analyses for sulfate-reducing bacteria revealed their presence in all samples. Microbial activity and sulfate removal obtained for AUT cultures indicated that they possess the potential for use in local acid mine drainage decontamination processes.

Keywords: Autochthonous microorganisms; Sulfate removal; Anaerobic batch reactor; Sulfate-reducing bacteria.
\end{abstract}

\section{INTRODUCTION}

The mining and metallurgical exploitation of sulfide minerals can lead to the formation of acid mine drainage (AMD) (Kaksonen et al., 2006). Acid mine drainage is produced by the oxidation of metal sulfides. This is possible when metal sulfides are exposed to air, water and catalyzed by autochthonous microorganisms existing in AMD (Sicupira et al., 2015). Besides its low organic carbon content, the resulting AMD has low $\mathrm{pH}$, high sulfate and metal concentrations, causing serious environmental problems (Sicupira et al., 2015).
Traditional chemical processes for AMD treatment have several disadvantages, such as the high cost of chemical reagents, inefficient sulfate removal, and large amounts of sludge generation (Kaksonen et al., 2006). Thus, biological anaerobic treatment is an important substitute for conventional AMD treatment due to its high efficiency, cost-effectiveness, and environmental safety.

The bioremediation of AMD using sulfate-reducing bacteria (SRB) is a viable alternative. SRB can use numerous types of chemicals as electron donors such as lactate (Equation 1, 2, 3), ethanol (Equation 4), and formate (Equation 5). In addition, SRB reduce sulfate

\footnotetext{
*Corresponding author: Gunther Brucha - E-mail: gunther.brucha@unifal-mg.edu.br
} 
$\left(\mathrm{SO}_{4}^{2-}\right)$ using electron donors, producing hydrogen sulfide $\left(\mathrm{H}_{2} \mathrm{~S}\right)$ and bicarbonate $\left(\mathrm{HCO}_{3}^{-}\right)$, as shown in Equations 1, 4, and 5 for a $\mathrm{COD} / \mathrm{SO}_{4}^{2-}$ ratio of 0.67 , and Equations 2 and 3 for $\mathrm{COD} / \mathrm{SO}_{4}^{2-}$ ratios greater than 0.67 (Dar et al., 2008). The produced bicarbonate can increase the $\mathrm{pH}$ to neutral or alkaline values (Sahinkaya et al., 2011). Moreover, the produced sulfide enables metal removal by forming stable metal sulfide precipitates (Bekmezcia et al., 2011).

$$
\begin{aligned}
& 2 \mathrm{C}_{3} \mathrm{H}_{5} \mathrm{O}_{3}^{-}+3 \mathrm{SO}_{4}^{2-}+2 \mathrm{H}^{+} \rightarrow 3 \mathrm{H}_{2} \mathrm{~S}+6 \mathrm{HCO}_{3}^{-} \\
& (\Delta \mathrm{G}=-128.5 \mathrm{~kJ} / \mathrm{mol})
\end{aligned}
$$

$$
\begin{aligned}
& 4 \mathrm{C}_{3} \mathrm{H}_{5} \mathrm{O}_{3}^{-}+3 \mathrm{SO}_{4}^{2-} \rightarrow 4 \mathrm{C}_{2} \mathrm{H}_{3} \mathrm{O}_{2}^{-1}+4 \mathrm{HCO}_{3}^{-}+3 \mathrm{HS}^{-1}+\mathrm{H}^{+} \\
& (\Delta \mathrm{G}=-37.7 \mathrm{~kJ} / \mathrm{mol})
\end{aligned}
$$

$$
\begin{aligned}
& 2 \mathrm{C}_{3} \mathrm{H}_{5} \mathrm{O}_{3}^{-}+\mathrm{SO}_{4}^{2-} \rightarrow 2 \mathrm{C}_{2} \mathrm{H}_{3} \mathrm{O}_{2}^{-1}+2 \mathrm{HCO}_{3}^{-}+\mathrm{HS}^{-1}+\mathrm{H}^{+} \\
& (\Delta \mathrm{G}=-80.8 \mathrm{~kJ} / \mathrm{mol})
\end{aligned}
$$

$$
\begin{aligned}
& \mathrm{CH}_{3} \mathrm{CH}_{2} \mathrm{OH}+1.5 \mathrm{SO}_{4}^{2-}+\mathrm{H}^{+} \rightarrow 2 \mathrm{HCO}_{3}^{-}+1.5 \mathrm{H}_{2} \mathrm{~S}+\mathrm{H}_{2} \mathrm{O} \\
& (\Delta \mathrm{G}=-80.2 \mathrm{~kJ} / \mathrm{mol})
\end{aligned}
$$

$$
\begin{aligned}
& 4 \mathrm{HCOO}^{-}+\mathrm{SO}_{4}^{2-}+2 \mathrm{H}^{+} \rightarrow 4 \mathrm{HCO}_{3}^{-}+\mathrm{H}_{2} \mathrm{~S} \\
& (\Delta \mathrm{G}=-58.4 \mathrm{~kJ} / \mathrm{mol})
\end{aligned}
$$

Despite the extreme conditions of acid mine drainage, SRB communities have already been found in acid mine drainage sediment samples, as reported by Muyzer and Stams (2008). However, stable enrichment using cultures provided from acidic environments is scarce, and only a few acidophilic or acid-tolerant SRB have been identified (Sánchez-Andrea et al., 2013). Thus, the study of SRB based on their enrichment is important in enabling the application of autochthonous and extremophile SRB as biomass in sulfidogenic reactors. As the carbon source is a limiting nutrient in AMD, the choice of a suitable lowcost carbon source that allows high sulfate reduction efficiency is important (Rodriguez and Zaiat, 2011). Although lactate is the preferred carbon source of SRB for sulfate reduction, it is not cost-effective. It is, therefore, necessary to use different electron donors during the enrichment process, such as ethanol, which is a cheaper substrate (Bertolino et al., 2014).

The capacity of SRB to survive in diverse environments makes possible the use of autochthonous SRB for the bioremediation of sulfate-rich wastewater, such as acid mine drainage, as they can adapt to different environmental conditions. This also suggests the importance of studying and identifying extremophile SRB obtained from AMD sediments, as well as exploring their metabolic activities and their complexity (Sánchez-Andrea et al., 2012).

Non-autochthonous communities have been considered adequate for the treatment of acidic water (Altun et al., 2014; Singh et al., 2011; Zhang and Wang, 2016). Promising results have been reported for the use of autochthonous microorganisms as inocula for acid mine drainage treatment in anaerobic reactors (Sánchez-Andrea et al., 2013; Martins et al., 2009). However, few studies have compared the potential of autochthonous communities with that of non-autochthonous cultures for bioremediation processes (Luptakova and Kusnierova, 2005). Table 1 below contains some examples of sulfate removal efficiencies for autochthonous and non-autochthonous inocula, consisting of anaerobic sludge:

The uranium mine site located in Poços de Caldas, Minas Gerais, Brasil is composed of low-pH waters (mean $\mathrm{pH} 3$ ), high concentrations of sulfate (15.6 mmol), ferric iron, and other heavy metals (Rodriguez et al., 2012). The physical-chemical treatment used to treat this wastewater is costly and generates a lot of sludge contaminated with uranium, thus failing to solve the environmental problem in a satisfactory way. As such, exploring the metabolic activities of

Table 1. Examples of sulfate removal efficiencies for non-autochthonous and autochthonous biomass.

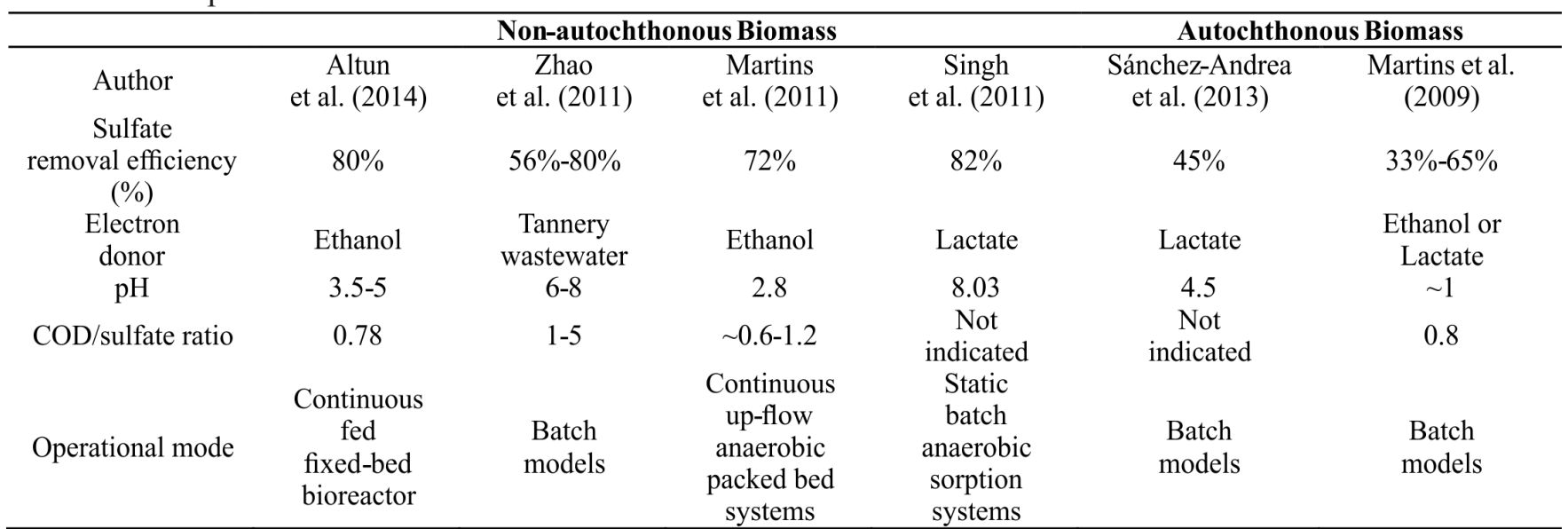


the microbial communities present at this mine site (Sánchez-Andrea et al. 2012), especially SRB, is a very important method to analyze the biotechnological potential of the microorganisms living in that adverse environment.

The purpose of this study was to compare the use of autochthonous cultures of the sediment of an uranium mine located in Poços de Caldas, Minas Gerais, Brazil and non-autochthonous biomass in bioremediation of AMD in anaerobic batch reactors using Postgate $\mathrm{C}$ as the enrichment medium. The performance based on sulfate removal and the microbial community of the autochthonous culture was analyzed, comparing it with non-autochthonous culture, as a way to identify similar efficiencies and specific extremophile microorganisms. Afterwards, the sulfate removal efficiencies of the enriched cultures on a modified Postgate $\mathrm{C}$ medium were studied to better understand the preferential and more readily degraded carbon sources for growth in neutral $\mathrm{pH}$ (here considering lactate, ethanol, and formate). A complementary study of autochthonous SRB enrichment in acidic $\mathrm{pH}$ was also conducted, evaluating the capacity for sulfate removal, and sulfide and carbonate production, including a denaturing gradient gel electrophoresis (DGGE) profile to show their presence, even in acidic $\mathrm{pH}$, and to study the bacterial community. The effect of the $\mathrm{COD} /$ sulfate ratio on sulfate removal efficiencies was also studied. Thus, the enrichment conditions based on carbon source, $\mathrm{pH}$, and $\mathrm{COD} /$ sulfate ratio were modified to identify the potential of autochthonous SRB for application to the decontamination of their original uranium mine site.

\section{MATERIALS AND METHODS}

\section{Phase 1: SRB enrichment in the Postgate $C$ medium Inoculum}

Two different biomass samples were used as inoculum: one from a stable sulfidogenic batch reactor using lactate as a carbon source (original inoculum from a slaughterhouse wastewater treatment plant; hereafter: N-AUT culture) and the other from an enrichment culture of the sediment of a uranium mine located in Poços de Caldas, Minas Gerais, Brazil, containing acid mine drainage (hereafter: AUT culture). Duplicates of the N-AUT culture were prepared by suspending $10 \mathrm{~mL}$ of the inoculum from a sulfidogenic reactor operating for 88 days with lactate at a $\mathrm{COD} / \mathrm{SO}_{4}{ }^{2-}$ ratio of 1.0 and treating synthetic acidic wastewater with a sulfate removal efficiency of $73 \%$ in $25-\mathrm{mL}$ distilled water. Duplicates of the AUT culture consisted of uranium acid mine drainage samples enriched in a Postgate $\mathrm{C}$ medium. In total, $184 \pm 20 \mathrm{mg} / \mathrm{L}$ of volatile solids from the N-AUT culture or $180 \pm 20 \mathrm{mg} / \mathrm{L}$ of volatile solids from the
AUT culture were added as inoculum to one of two $500-\mathrm{mL}$ anaerobic batch reactors containing $250 \mathrm{~mL}$ of a Postgate C medium (Reactor N-AUT and Reactor AUT, respectively).

\section{Enrichment Medium}

SRB were enriched using a Postgate $\mathrm{C}$ medium composed of $3.0 \mathrm{~g} / \mathrm{L}$ sodium lactate (carbon source and electron donor), $0.3 \mathrm{~g} / \mathrm{L}$ sodium citrate, $0.1 \mathrm{~g} / \mathrm{L}$ yeast extract, $0.5 \mathrm{~g} / \mathrm{L} \mathrm{KH}_{2} \mathrm{PO}_{4}, 1.0 \mathrm{~g} / \mathrm{L} \mathrm{NH}_{4} \mathrm{Cl}, 4.5 \mathrm{~g} / \mathrm{L}$ $\mathrm{Na}_{2} \mathrm{SO}_{4}, 0.04 \mathrm{~g} / \mathrm{L} \mathrm{CaCl} \cdot 2 \mathrm{H}_{2} \mathrm{O}, 0.06 \mathrm{~g} / \mathrm{L} \mathrm{MgSO}_{4} \cdot 7 \mathrm{H}_{2} \mathrm{O}$, $0.004 \mathrm{~g} / \mathrm{L} \mathrm{FeSO}_{4} \cdot 7 \mathrm{H}_{2} \mathrm{O}, 0.001 \mathrm{~g} / \mathrm{L}$ Resazurin, and 0.5 $\mathrm{g} / \mathrm{L} \mathrm{Na} \mathrm{Na}_{2} \mathrm{~S}$. The $\mathrm{COD} /$ sulfate ratio used was $1.20 \pm$ 0.16 and $1.25 \pm 0.18$, for Reactors AUT and Reactor N-AUT, respectively.

\section{Experimental Protocol}

Both reactors were sterilized, maintained under a constant flow of nitrogen prior to inoculation, and subsequently, kept aseptic during the experiment. The systems were incubated at $30^{\circ} \mathrm{C}$ with agitation at $100 \mathrm{rpm}$ for 41 consecutive days without medium replacement. A control reactor (Control), which was sterilized and maintained under a constant flow of nitrogen prior to inoculation, was kept aseptic after inoculation, containing no inoculum and $250 \mathrm{~mL}$ of a Postgate $\mathrm{C}$ medium, and was operated under the same conditions as used in experimental Phase I. The nitrogen flow was ceased in all reactors after inoculation.

\section{Phase 2: SRB enrichment in the modified Postgate C medium Inoculum}

As inoculum, $180 \pm 20 \mathrm{mg} / \mathrm{L}$ of total volatile solids from the AUT culture were added to $500-\mathrm{mL}$ anaerobic batch reactors containing $250 \mathrm{~mL}$ of a modified Postgate $\mathrm{C}$ medium. AUT culture consisted of uranium acid mine drainage samples enriched in a Postgate $\mathrm{C}$ medium.

\section{Enrichment Medium}

The AUT culture was enriched using a Postgate C medium, which was modified by altering the carbon source from lactate (Reactors LAC) to ethanol (Reactors ETA) or formate (Reactors FOR; maintaining 26.8$\mathrm{mM}$ concentration) and by reducing the enrichment medium initial $\mathrm{pH}$, previously to inoculation (Table 2).

\section{Experimental Protocol}

The reactors were duplicated, except for reactor FOR 3 (initial $\mathrm{pH} 3$ ) for which they were triplicated. The reactors were sterilized and maintained under a constant flow of nitrogen before use, and were kept aseptic during the experiment. The systems were incubated at $30^{\circ} \mathrm{C}$, with agitation at $100 \mathrm{rpm}$ 
Table 2. Carbon sources and initial pH used on studied reactors.

\begin{tabular}{cccc}
\hline $\begin{array}{c}\text { Carbon } \\
\text { Source }\end{array}$ & $\begin{array}{c}\text { Initial } \\
\mathbf{p H}\end{array}$ & $\begin{array}{c}\mathbf{C O D} \text { /sulfate } \\
\text { ratio }\end{array}$ & $\begin{array}{c}\text { Reactor } \\
\text { Denomination }\end{array}$ \\
\hline \multirow{4}{*}{ Lactate } & - & - & Control LAC \\
& $7.34 \pm 0.10$ & $1.08 \pm 0.09$ & LAC 7 \\
& $3.96 \pm 0.10$ & $1.15 \pm 0.10$ & LAC 4 \\
& $3.03 \pm 0.10$ & $1.27 \pm 0.12$ & LAC 3 \\
Control ETA \\
Ethanol & - & & ETA 7 \\
& $3.41 \pm 0.10$ & $1.27 \pm 0.10$ & ETA 4 \\
& $2.70 \pm 0.10$ & $0.95 \pm 0.09$ & ETA 3 \\
& - & $1.06 \pm 0.09$ & Control FOR \\
Formate & $7.05 \pm 0.10$ & $1.20 \pm 0.11$ & FOR 7 \\
& $4.02 \pm 0.10$ & $1.09 \pm 0.10$ & FOR 4 \\
& $2.89 \pm 0.10$ & $1.02 \pm 0.08$ & FOR 3 \\
\hline
\end{tabular}

and without medium replacement. The experiments were conducted for approximately 35 days at neutral $\mathrm{pH}$ and for 24 days at an acidic $\mathrm{pH}$. The enrichment period was determined based on the reduction of the cultivation medium, indicated by the redox potential. The enrichments were considered finished when the culture medium terminated sulfide production and the medium was no longer transparent, indicating that the redox potential had become greater than $-200 \mathrm{mV}$, a suitable condition for SRB growth (Jing and Kjellerup, 2017). Thus, at the end of the experiments, when the medium turned pink, caused by the indicator Resazurin, the presence of a semi-reduced medium could be inferred, no longer capable of stabilizing the sulfate removal process. The duplicate reactors fed with lactate (Control LAC), ethanol (Control ETA), or formate (Control FOR), containing no inoculum and $250 \mathrm{~mL}$ of a modified Postgate C medium, were operated under the same conditions.

A summary of Phase 1 and Phase 2 experimental procedures are found in the flowchart below:

\section{Physical and chemical analysis}

The samples were centrifuged using an MCD-2000 HEMATOCRIT micro-type centrifuge at $8000 \mathrm{rpm}$ for 10 min prior to COD and sulfate measurements. The COD (5220 D), pH (4500- $\left.\mathrm{H}^{+} \mathrm{B}\right)$, total volatile solids (2540 Solids), sulfate (4500- $\mathrm{SO}_{4}^{2-} \mathrm{E}$ ), and dissolved sulfides (4500-S- $\mathrm{S}^{2-}$ ) were monitored based on American Public Health Association standards (APHA, 2012). The COD, sulfate, and sulfide concentrations were determined every 2-3 days, whereas the $\mathrm{pH}$ was measured only at the beginning and end of enrichment. SRB were enumerated using the most probable number (MPN) method, as described in APHA (2012).

Errors in analytical precision were estimated using standard errors and R software version 3.4.4 (R Core Team, 2018). Uncertainties were calculated using the protocols of Miller and Miller (2010) and Thompson et al. (2002). The t-student distribution for a 95\% confidence interval was used for each analysis.

\section{Microbial community analysis}

For Phase 1, samples from both the AUT and $\mathrm{N}$-AUT reactors were taken at different times during the one-month enrichment process to study the domain bacteria and SRB diversity via polymerase chain reaction $(\mathrm{PCR})$ and denaturing gradient gel electrophoresis (DGGE) analysis. In total, five samples were collected from each reactor. The biomass samples

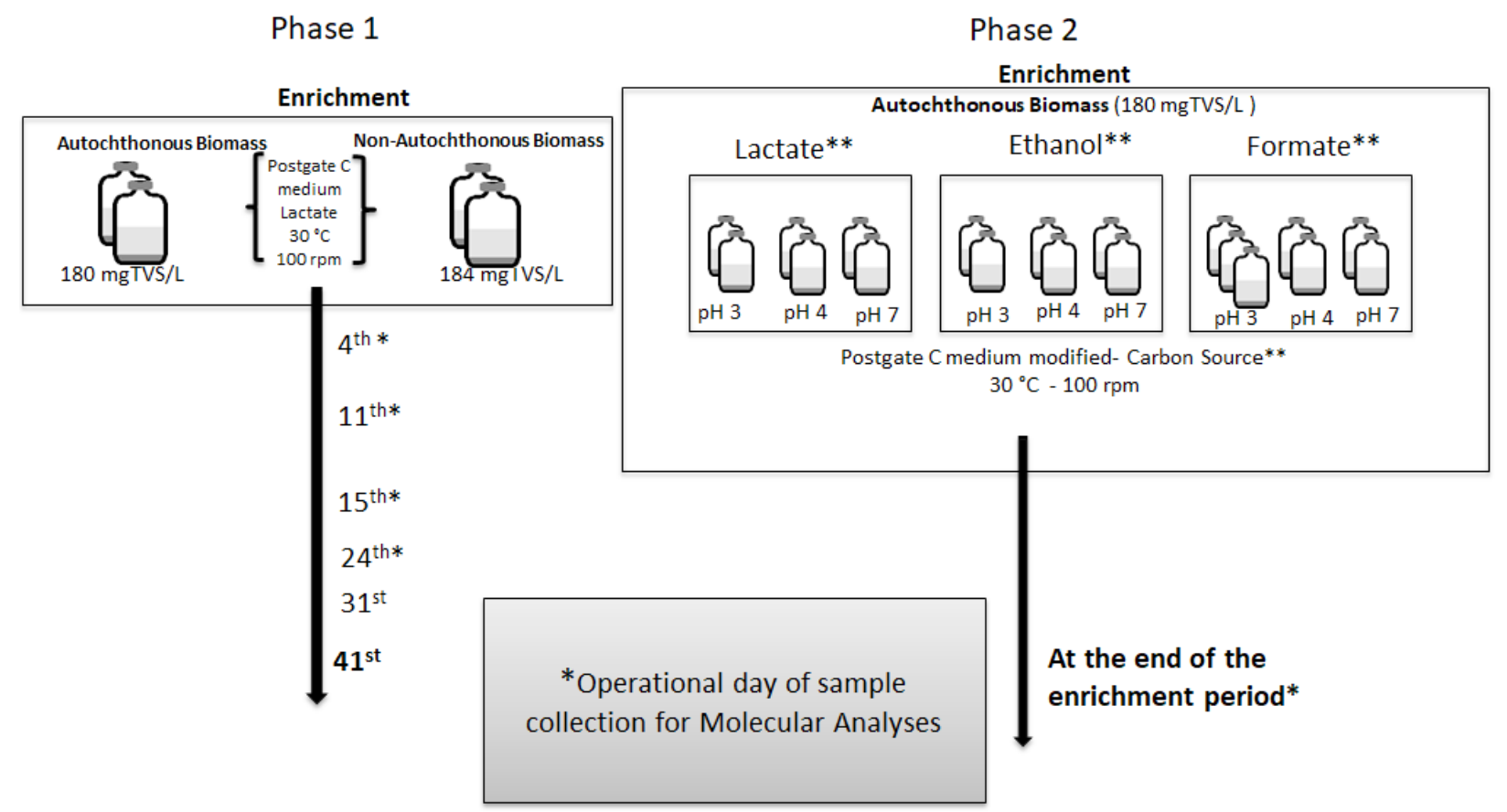

Figure 1. Summary of experimental phases (Phase 1 and Phase 2). 
from the AUT reactor consisted of homogeneous cell suspensions in a Postgate $\mathrm{C}$ medium. The samples of the N-AUT reactor consisted of enriched cultures of $\mathrm{N}$-AUT sludge in a Postgate $\mathrm{C}$ medium. The AUT 1 and N-AUT 1 samples were collected on operational day 4 from reactors AUT and N-AUT, respectively; the AUT 2 and N-AUT 2 samples were collected on operational day 11; the AUT 3 and N-AUT 3 samples were obtained on operational day 15; the AUT 4 and N-AUT 4 samples were taken on operational day 24; and the AUT 5 and N-AUT 5 samples were collected on operational day 31 .

For Phase 2, biomass samples (cell suspensions) from reactors LAC 4, LAC 3, ETA 7, ETA 4, ETA 3, FOR 7, FOR 4, and FOR 3 were taken at the end of the enrichment period and named based on the reactor denomination. Molecular analyses were not performed for the LAC 7 reactor because it had been cultivated under the same conditions as the AUT reactor samples that were already analyzed in Phase 1 . The collected samples were maintained at $-20{ }^{\circ} \mathrm{C}$ prior to deoxyribonucleic acid (DNA) extraction.

All molecular analyses were performed under aseptic conditions using aseptic techniques.

\section{DNA extraction}

The total DNA was extracted using a Wizard $\AA$ Genomic DNA Purification Kit (Promega $\AA$ ), according to the manufacturer's instructions. The DNA extraction was confirmed by electrophoresis (DIGEL ${ }^{\circledR}$ ) on $1.5 \%$ agarose gels at $120 \mathrm{~V}$ for $30 \mathrm{~min}$ (Geets et al., 2006; Lee et al., 2012).

\section{PCR and DGGE analyses}

All DNA-extracted samples were analyzed using PCR and DGGE. For PCR analysis, a 50- $\mu \mathrm{L}$ mixture consisting of $10-\mathrm{mM}$ Tris- $\mathrm{HCl}$ buffer, $1.5-\mathrm{mM} \mathrm{MgCl}_{2}$, $0.2 \mathrm{mM}$ of each dNTP, $0.5 \mathrm{U}$ of Taq DNA polymerase (Promega), $0.2 \mu \mathrm{mol}$ of each primer, and $50-100 \mathrm{ng}$ of DNA was used. The dissimilatory sulfite reductase subunit B gene (dsrB) was amplified via PCR using the forward and reverse primers DSRp2060F (5'-CAACATCGTYCAYACCCAGGG-3') and DSR4R (5'-GTGTAGCAGTTACCGCA-3'), respectively (Lopez et al., 2014). The bacterial 16S rRNA gene was amplified using the forward and reverse primers $968 \mathrm{~F}$ (5'-AAC GCG AAG AAC CTT AC) and 1401R (5' CGG TGT GTA CAA GGC CCG GGA ACG), respectively (Heuer et al., 1997). The 5' ends of the forward primers were GC-clamped (5' CGC CCG CGC GCGGCG GGC GGG GCG GGG GCA CGG GGG G) as suggested by Geets et al. (2006). Amplification was performed using a MaxyGene Gradient Thermal Cycler (Axygen) according to the following protocol: initial denaturation step at $94{ }^{\circ} \mathrm{C}$ for $4 \mathrm{~min}$; 35 cycles of denaturation at $94{ }^{\circ} \mathrm{C}$ for $1 \mathrm{~min}$, primer annealing at $55{ }^{\circ} \mathrm{C}$ for $1 \mathrm{~min}$ and extension at $72{ }^{\circ} \mathrm{C}$ for $1 \mathrm{~min}$; and final extension step at $72{ }^{\circ} \mathrm{C}$ for $10 \mathrm{~min}$ (Geets et al., 2006). Electrophoresis using a DIGEL $®$ system with $1.5 \%$ agarose gels (Geets et al., 2006) at $120 \mathrm{~V}$ for 30 min was used to confirm the PCR amplification (Lee et al., 2012).

For DGGE analyses, a Loccus Biotecnologia system was used at $85 \mathrm{~V}$ and $60{ }^{\circ} \mathrm{C}$ for $17 \mathrm{~h}$ in a $7.5 \%$ polyacrylamide gel with a $40 \%-60 \%$ urea-formamide denaturing gradient (Ceccherini et al., 2009; Shi et al., 2012). BioNumerics ${ }^{\circledR}$ software (Applied Maths) employing the Dice coefficient and unweighted pairgroup method with arithmetic mean (UPGMA) was used to analyze the DGGE profiles (Geets et al., 2006).

\section{DsrB gene sequencing for SRB analysis}

The bands from the dsrB DGGE were excised and reamplified using the same primers used for the initial DGGE, excluding the GC clamp, as suggested by Geets et al. (2006). A Wizard $®$ SV Gel and PCR Clean-Up System (Promega) was employed to purify the reamplified products. An ABI 3730 DNA analyzer (Perkin-Elmer) was used to sequence the reamplified bands. The sequenced bands were registered in the GenBank database with the following accession numbers: KX351203, KX351204, KX351205, KX351206 and KX351207. Sequence alignment within the GenBank database was performed using a BLASTN program (Geets et al., 2006; Meyer and Kuever, 2007). An unrooted phylogenetic tree comparing the sequenced bands with some of their closest relatives retrieved from the GenBank database was constructed using the neighbor-joining method and MEGA 5.0 software.

\section{RESULTS AND DISCUSSION}

\section{Phase 1: Performance of the AUT and N-AUT reactors}

The extent of sulfate reduction by the AUT and N-AUT reactors was similar (summarized in Table 3 and Figure 2). A maximum sulfate removal of $53 \%$ and $59 \%$ was obtained in the AUT and N-AUT reactors, respectively, for a medium $\mathrm{COD} /$ sulfate ratio of $1.22 \pm 0.24$. Oyekola et al. (2010) also observed

Table 3. Physical-chemical parameters for Phase 1 cultivation.

\begin{tabular}{ccc}
\hline Parameter" & $\begin{array}{c}\text { Reactor } \\
\text { AUT }\end{array}$ & $\begin{array}{c}\text { Reactor } \\
\text { N-AUT }\end{array}$ \\
\hline Initial pH & $6.55 \pm 0.10$ & $6.35 \pm 0.10$ \\
Final pH & $7.86 \pm 0.10$ & $7.91 \pm 0.10$ \\
COD/SO ${ }^{2-}$ & $1.20 \pm 0.16$ & $1.25 \pm 0.18$ \\
Maximum COD removal (\%) & $27.3 \pm 3.4$ & $88.2 \pm 3.7$ \\
Maximum SO ${ }^{2-}$ removal (\%) & $53 \pm 15$ & $59 \pm 17$ \\
$\mathrm{~S}^{2-}$ production (mmol) & $19.0 \pm 0.8$ & $20.8 \pm 0.8$ \\
${ }^{*}$ The parameters were calculated using the arithmetic & average of the
\end{tabular}
duplicate reactors. 


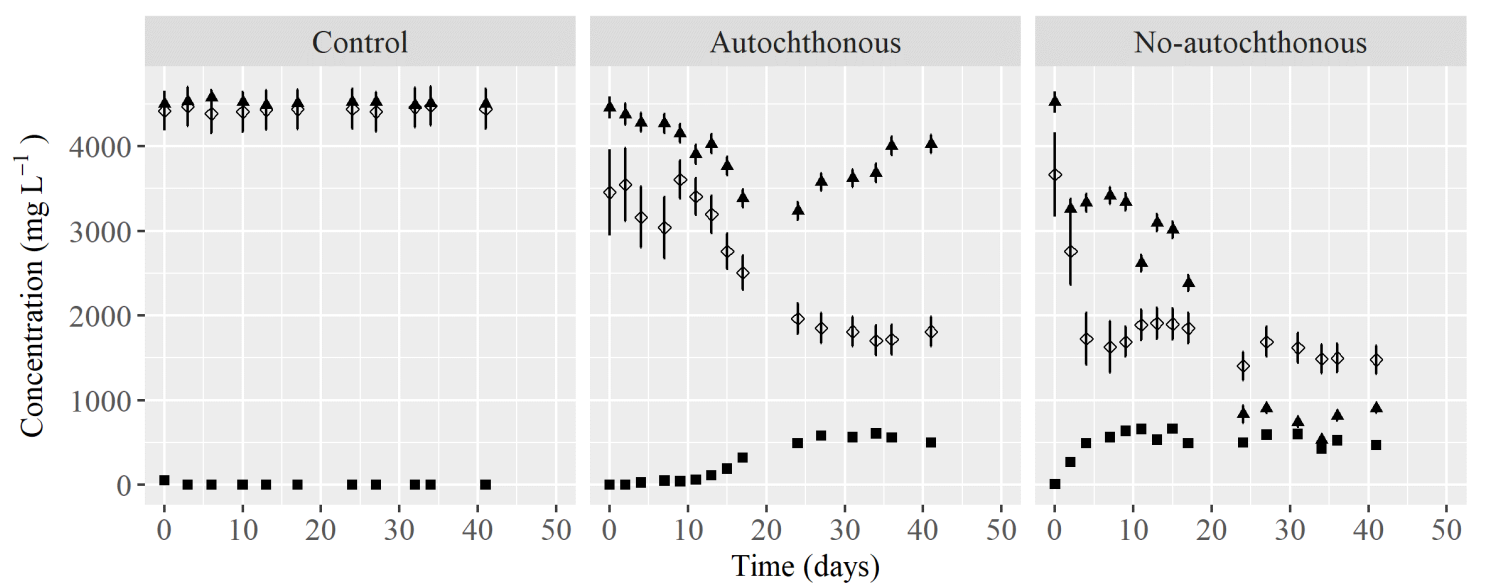

Figure 2. Performance of the control, autochthonous, and non-autochthonous reactors during the experiments (COD $(\boldsymbol{\bullet}), \mathrm{SO}_{4}^{2-}(\diamond)$ and sulfide $(\boldsymbol{\square})$ concentrations). The error bars correspond to $95 \%$ confidence interval.

similar sulfate removal efficiencies, varying from $42 \%$ to $58 \%$ for a $\mathrm{COD} / \mathrm{SO}^{2-}$ ratio of 1.2 . The poor sulfate removal observed in AUT and N-AUT reactors, lower than $70 \%$, was probably due the limiting COD/ sulfate ratio used in the sulfidogenic process. Dar et al. (2008) observed that when a COD/sulfate ratio of 2.0 was used, nearly all sulfate was converted to sulfide, which did not occur for a COD/sulfate ratio of 0.34 , where almost all the sulfate remained in the effluent. The interesting point of view of this study is that SRB were the dominant group when using the lower stoichiometry $\mathrm{COD} /$ sulfate ratio (relative abundance $\sim 75 \%$ ), while the other condition presented a diverse microbial group in which SRB were not the most dominant (relative abundance $\sim 25 \%$ ). Lu et al. (2016) also reported that the decrease in the $\mathrm{COD} / \mathrm{SO}_{4}{ }^{2-}$ ratio from 5 to 1 caused the reduction in sulfate removal from $82 \%$ to $21 \%$.

The COD removal of the AUT and N-AUT reactors was very different, $27 \%$ and $88 \%$, respectively. Based on the stoichiometric relation of 0.67 , a sulfate removal of $19.2 \pm 5.6 \mathrm{mmol}$ and lactate consumption of $12.8 \pm$ $1.1 \mathrm{mmol}$ are expected for the AUT reactor if lactate was completely oxidized, as shown in Equation 1. The lactate removal observed in the present experiment was $12.7 \pm 0.6 \mathrm{mmol}$, which is similar to the expected value. The biomass of the AUT reactor was adapted and isolated from the acid mine drainage sediment of an uranium mine; the SRB richness of this inoculum was lower (Figure 3) than that of the N-AUT reactor because the AUT reactor was probably dominated by a sulfidogenic-specialized genus capable of complete oxidation.

The lactate consumption in the N-AUT reactor expected for a sulfate removal of $22.1 \pm 5.9 \mathrm{mmol}$ based on the stoichiometry for complete oxidation is $14.7 \pm 1.3 \mathrm{mmol}$. A lactate removal of $41.6 \pm 0.5 \mathrm{mmol}$ was obtained, corresponding to the stoichiometry relation of Equation 3 ( $1 \mathrm{~mol}$ of $\mathrm{SO}_{4}{ }^{2-}$ can consume
2 mol of lactate), an incomplete route. As the N-AUT inoculum includes a consortium of microorganisms, the incomplete consumption of lactate may have promoted the establishment of different microorganism species and syntrophic relationships of SRB with other microorganisms such as methanogenic archaea and acetogenic bacteria (Muyzer and Stams, 2008). In addition, it seemed that in reactor N-AUT a twostep reaction occurred. First, lactate was incompletely oxidized to acetate with sulfate and an excess of lactate, according to Equation 3. Then, the produced acetate could be assimilated by methanogens, as shown in Equation 6 below:

$\mathrm{C}_{2} \mathrm{H}_{3} \mathrm{O}_{2}^{-1}+\mathrm{H}_{2} \mathrm{O} \rightarrow \mathrm{CH}_{4}+\mathrm{HCO}_{3}^{-}$

AUT and N-AUT reactors showed similar sulfide production values. However, the AUT reactor presented two stages of sulfide production (Figure 2). The first stage occurred during the first 10 days in which no sulfide accumulation was observed. The second stage was 14 days long (days 11-25), corresponding to high sulfide production. Vainshtein et al. (2003) also noted two stages of sulfate reduction in a bacterial consortium isolated from a soil sample of an aerobic/ anaerobic gradient ecosystem: a slow adaptation stage, with no accumulation of hydrogen sulfide, and a rapid sulfate removal stage, with sulfide accumulation and the generation of sulfur intermediates, such as thiosulfate and sulfite.

An adaptation time of $\sim 10$ days was necessary for the AUT culture (Figure 2), also observed by Martins et al. (2009) when studying metal-resistant SRB for acid mine drainage treatment in batch reactors under anaerobic conditions. The autochthonous SRB were more affected by the initial $\mathrm{COD} / \mathrm{SO}^{2-}$ ratio, as the sulfate loading rate was lower, $0.45 \mathrm{mmol}^{-\mathrm{d}^{-1}}$ compared to $0.57 \mathrm{mmol}^{\mathrm{d}} \mathrm{d}^{-1}$, for the N-AUT culture. According to Hwang and Jho (2018), a lag time is 
necessary for the bacterial community to exhibit its sulfate reducing capacity. In addition, the lower sulfate loading rates found in autochthonous bacterial communities can also be attributed to the composition of their bacterial community. As we can see in Figure 3 , non-autochthonous communities exhibited a diverse SRB group compared to the autochthonous reactor. In addition, during the AUT biomass lag phase, the sulfide and sulfate concentrations were mostly stable. This was not the case for the N-AUT reactor, as during the same period high sulfate removal and sulfide production were observed. Thus, because the N-AUT biomass was pre-acclimated in a stable sulfidogenic reactor at lower $\mathrm{pH}$ values and, perhaps, exposed to high sulfate content, it conferred a faster capacity to remove sulfate with no need for adaptation to the new culture medium. This was also observed by Rodriguez and Zaiat (2011), who reported no need of a lag phase when an anaerobic sludge was used as inoculum for common substrates of sulfate reduction, such as lactate. However, it is important to emphasize that after this acclimation period required by the AUT culture, both cultures had similar sulfate removal and sulfide production values (Table 3). Thus, it is important to conduct a complementary study of organic substrates more readily degraded by autochthonous bacteria than lactate (like ethanol and formate), as a way to reduce the lag phase found in Phase 1.

\section{Comparative evaluation of the microbial community}

Similarity dendrograms and DGGE profiles for the domain Bacteria and the SRB group are shown in
Figure 3. The N-AUT and AUT reactors had distinct community structures, with a similarity of only $42 \%$ for the domain Bacteria and 12\% for the SRB group. The diversities of the domain Bacteria and SRB were mostly stable during the enrichment. Both reactors showed a high microbial diversity for the domain Bacteria during the cultivation period (Figure 3a). For the SRB group, the AUT reactor showed one predominant band compared with the high diversity of the N-AUT reactor (Figure $3 b$ ).

It was not possible to amplify the SRB dsrB gene during the first two weeks of enrichment in the AUT reactor (samples AUT 1 and AUT 2; Figure $3 \mathrm{~b}$ ). This period corresponded to the adaptation time and low sulfide production (Figure 2). The low SRB numbers during this cultivation period were probably not sufficient to allow PCR amplification and DGGE analyses of that group. This did not occur during the Bacterial 16S rRNA gene PCR and DGGE analyses (Figure 3a).

The phylogenetic tree (Figure 4) and the phylogenetic affiliations of the sequenced dsrB DGGE bands (Table 4) indicate that Band 1 of the AUT reactor shows more similarity to the Desulfotomaculum genus, which belongs to the class Clostridia, whereas the other bands isolated from the $\mathrm{N}$-AUT reactor were more similar to the Desulfovibrio genus, which belongs to the class Deltaproteobacteria. Species of the Desulfovibrio genus were the fastest growing SRB, using low molecular weight organic acids as substrates such as lactic acid, acetic acid, and ethanol (Cabrera et al., 2005). When lactate is

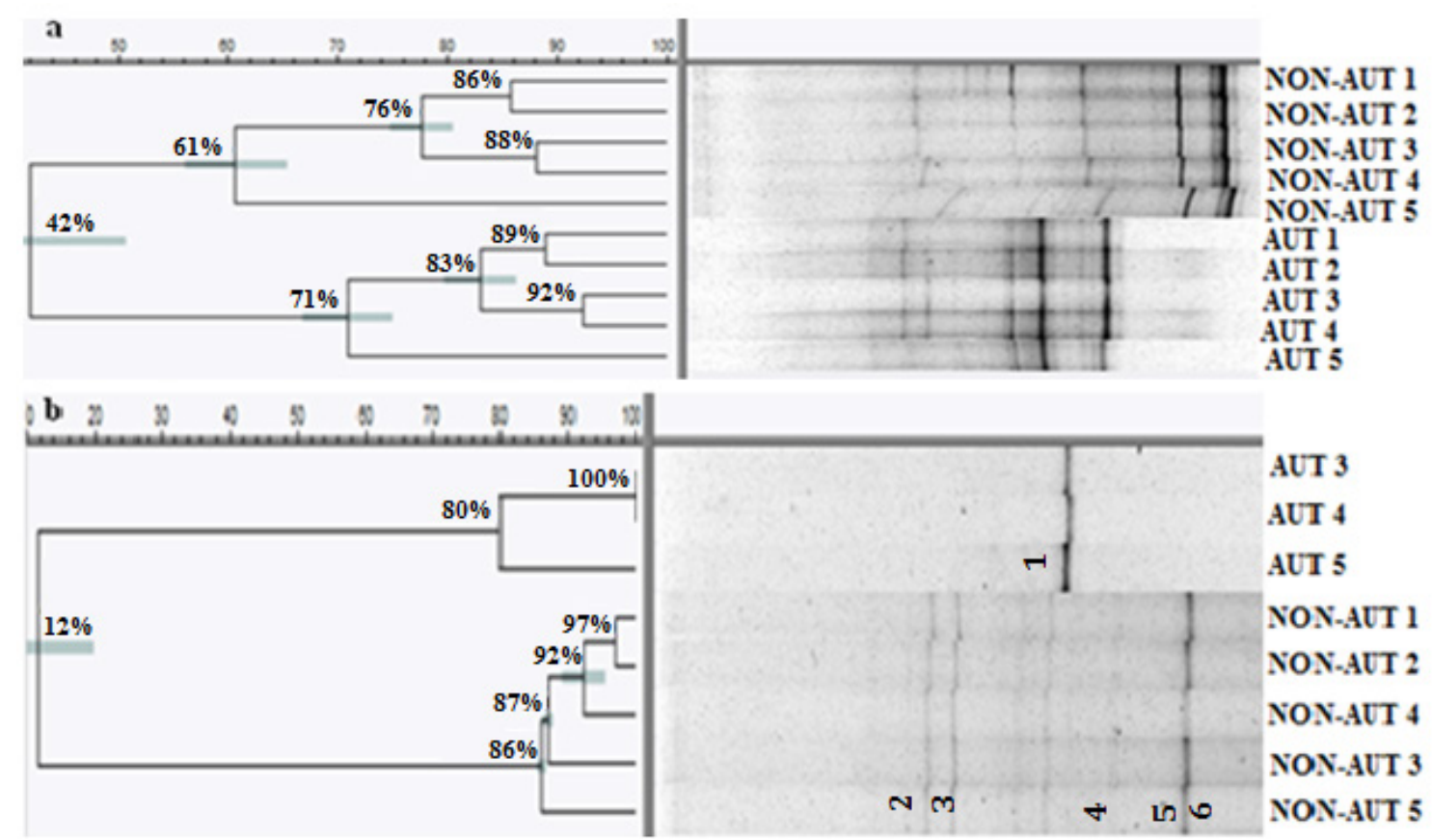

Figure 3. Similarity dendrograms (L) obtained using the BioNumerics program version 7.6 (Applied Maths, Belgium) and the Dice coefficient, UPGMA method and the DGGE gels (R) for the Bacterial 16S rRNA (a) and dsrB genes (b). The numbers in the gel images (b) represent sequenced bands. 


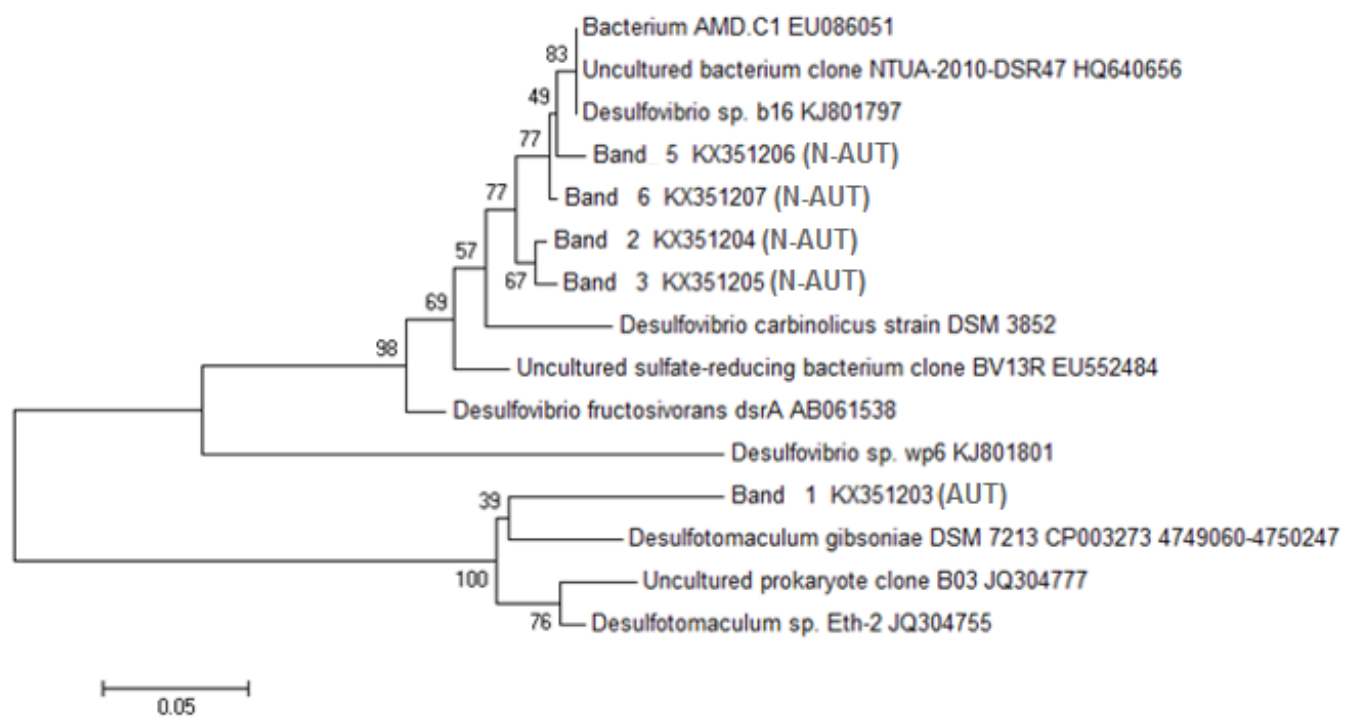

Figure 4. Phylogenetic tree constructed by comparing the sequenced bands from the dsrB gene DGGE profile with some of the closest relatives retrieved from the GenBank database. The tree was created using the neighbor-joining method and MEGA 5.0 software. The bootstrap values are indicated at the nodes. The scale bar represents two nucleotide substitutions per 100 nucleotides.

Table 4. Phylogenetic affiliations of bands sequenced from the dsrB gene DGGE profile.

\begin{tabular}{|c|c|c|c|c|c|}
\hline $\begin{array}{c}\text { Band (GenBank } \\
\text { Accession } \\
\left.\text { Number }{ }^{a}\right) \\
\end{array}$ & $\begin{array}{c}\text { Closest Sequence } \\
\text { (GenBank Accession } \\
\text { Number) } \\
\end{array}$ & $\begin{array}{l}\text { Similarity } \\
\text { (Query } \\
\text { Cover) }^{b} \\
\end{array}$ & $\begin{array}{c}\text { Closest cultured strain } \\
\text { (GenBank Accession } \\
\text { Number) } \\
\end{array}$ & $\begin{array}{c}\text { Similarity } \\
\text { (Query } \\
\text { Cover) }^{b} \\
\end{array}$ & $\begin{array}{l}\text { Phylogenetic } \\
\text { group }\end{array}$ \\
\hline $1(\mathrm{KX} 351203)$ & $\begin{array}{c}\text { Desulfotomaculum } \\
\text { gibsoniae DSM } 7213 \\
\text { (CP003273) }\end{array}$ & $91 \%(100 \%)$ & $\begin{array}{l}\text { Desulfotomaculum } \\
\text { gibsoniae DSM } 7213 \\
\text { (CP003273) }\end{array}$ & $91 \%(100 \%)$ & Clostridia \\
\hline $2(\mathrm{KX} 351204)$ & $\begin{array}{c}\text { Bacterium AMD.C1 } \\
\text { (EU086051) }\end{array}$ & $97 \%(100 \%)$ & $\begin{array}{c}\text { Desulfovibrio } \\
\text { fructosivorans JJ DSM } \\
3600(\mathrm{AF} 418187)\end{array}$ & $97 \%(95 \%)$ & Deltaproteobacteria \\
\hline 3 (KX351205) & $\begin{array}{l}\text { Bacterium AMD.C1 } \\
\text { (EU086051) }\end{array}$ & $97 \%(100 \%)$ & $\begin{array}{c}\text { Desulfovibrio magneticus } \\
\text { RS-1 (AP010904) }\end{array}$ & $94 \%(100 \%)$ & Deltaproteobacteria \\
\hline $5(\mathrm{KX} 351206)$ & $\begin{array}{l}\text { Bacterium AMD.C1 } \\
\text { (EU086051) }\end{array}$ & $98 \%(100 \%)$ & $\begin{array}{c}\text { Desulfovibrio carbinolicus } \\
\text { strain DSM } 3852\end{array}$ & $94 \%(100 \%)$ & Deltaproteobacteria \\
\hline $6(\mathrm{KX} 351207)$ & $\begin{array}{l}\text { Bacterium AMD.C1 } \\
\text { (EU086051) }\end{array}$ & $99 \%(100 \%)$ & $\begin{array}{l}\text { Desulfovibrio magneticus } \\
\text { RS-1 DNA (AP010904) }\end{array}$ & $94 \%(99 \%)$ & Deltaproteobacteria \\
\hline
\end{tabular}

${ }^{\mathrm{a} A c c e s s i o n}$ number of the sequenced bands in this study in the GenBank database; ${ }^{\mathrm{b}}$ Defined using a BLASTN search tool.

used as an electron donor for sulfate reduction, these SRB incompletely oxidize it to acetate (Zhang and Wang, 2016). Desulfotomaculum genus, otherwise, is known for their capacity to grow on a large variety of substrates, including organic compounds, longchain fatty acids, and several aromatic compounds. The oxidation of the substrates (to $\mathrm{CO}_{2}$ ) is usually complete; however, acetate and other fatty acids can accumulate when high substrate concentrations are observed (Kuever et al., 1999).

Species of the Desulfotomaculum genus are also capable of sporulation (Kuever et al. 1999), which explains the presence of only one predominant band in the AUT reactor DGGE gel of the SRB group, which is probably a specialized SRB group. The spore formation capacity enables the survival and adaptation of these microorganisms under unfavorable conditions, such as extreme acidic conditions present in acid mine drainage. This, along with the abovementioned metabolic adaptability, could also explain the significant differences in the DGGE profiles of the AUT and N-AUT reactors. This also could be the reason why the sulfate removal efficiency and sulfide production at neutral conditions were similar in both reactors, showing that this autochthonous population obtained at extreme conditions can be as effective with respect to the geochemical performance as nonautochthonous cultures. Moreover, despite the low diversity of the SRB group in the AUT reactor, the relatively high diversity found in the domain Bacteria could also have contributed to the overall performance of the reactor, with bacterial groups providing useful intermediary metabolic products for SRB in a cooperative relationship, contributing to COD removal rates. The diversity in the bacterial community and the functional role of the corresponding partners 
may explain the effectiveness of acid mine drainage bioremediation (Martins et al. 2011).

The study of an acid mine drainage bioremediation system based on sulfate reduction during high acid treatment by $\mathrm{Lu}$ et al. (2011) showed that Desulfotomaculum species can tolerate extremely low-pH (1 and 2) conditions and heavy metal presence, such as copper $(1.5 \mathrm{mg} / \mathrm{L})$ and zinc $(1.5$ $\mathrm{mg} / \mathrm{L}$ ), while maintaining efficient sulfate removal. In the present work, an SRB group affiliated with Desulfotomaculum in the AUT reactor demonstrated sulfate removal similar to that of the SRB group in the N-AUT reactor (Figure 2), despite the lower diversity. This performance result and the acid tolerance of Desulfotomaculum organisms indicate that employing this SRB group can lead to significant environmental advances in local acid mine drainage bioremediation.

\section{Phase 2: Performance and microbial communities of the $L A C$, ETA, and FOR reactors}

Sulfate removal was observed in all reactors of Phase 2 (Table 5). The SRB presence in all reactors under neutral and acidic conditions was confirmed via the DGGE profile of the SRB group (Figure 5a). The efficiencies of sulfate removal for LAC 7, ETA 7, and FOR 7 reactors were $44 \%, 42 \%$, and $34 \%$ respectively, values lower than expected based on other studies (Cao et al., 2012; Vilela et al., 2014; Bertolino et al., 2012). The $\mathrm{COD} / \mathrm{SO}_{4}{ }^{2-}$ ratio used in the experiments, lower than 1.27, might have affected the sulfate removal efficiencies and the SRB activity. According to Vilela et al. (2014), when a COD/sulfate ratio of 1 was used for ethanol as electron donor, the efficiency of sulfate removal was reduced from $80 \%$ (at a COD/sulfate ratio of 1.9 ) to $60 \%$. In addition, a sulfate removal efficiency of $74 \%$ was found when a COD/sulfate ratio of 3 was used for formate as an electron donor.
According to Bertolino et al. (2012), a COD/sulfate ratio of 2.0 is optimum for bacterial growth, resulting in sulfate removal rates of $98 \%$. In addition, Yuan et al. (2015) also conclude that the sulfate removal efficiency is improved with an increase in the COD/ sulfate ratio from 0.67 to 2.0. As discussed for Phase 1 , a limiting $\mathrm{COD} /$ sulfate ratio of $1.08 \pm 0.09$ used for the $\mathrm{LAC}$ reactor might be responsible to the reduction in sulfate removal efficiency.

The $\mathrm{pH}$ was not controlled in the beginning of the experiments as, after inoculation, the value can be altered depending on the carbon source used, making this variable difficult to control. Besides that, all studied reactors were operated with neutral $\mathrm{pH}$ (77.4), in a range of optimal $\mathrm{pH}$ for most known SRB (Rampinelli et al., 2008). Thus, this variable might not have affected the sulfate removal efficiencies and SRB activity. The sulfate removal rates were $0.58 \mathrm{mmol}^{-1}$ for the LAC reactor, $0.70 \mathrm{mmol}^{-1} \mathrm{~d}^{-1}$ for the ETA reactor, and much higher for the FOR reactor, a value of 1.83 mmol. $\mathrm{d}^{-1}$. According to Cao et al. (2012), the choice of electron donors has substantial impact on the rate of sulfate reduction. They also found that formate as electron donor promoted the fastest reduction of sulfate.

According to Table 5, similar sulfate removals were observed in the LAC 7, ETA 7, and FOR 7 reactors, as considering the calculated errors no significant differences were found. Sahinkaya and Yucesoy (2010) also found that substituting lactate with ethanol as a substrate in sulfidogenic reactors did not affect the sulfate removal efficiencies or system performance. Wolicka et al. (2015) obtained lower sulfate removals than those observed in this study ( $25 \%$ and $30 \%$ for lactate and ethanol, respectively, as carbon sources) when SRB communities enriched on a modified Postgate $\mathrm{C}$ medium were used as inoculum in the

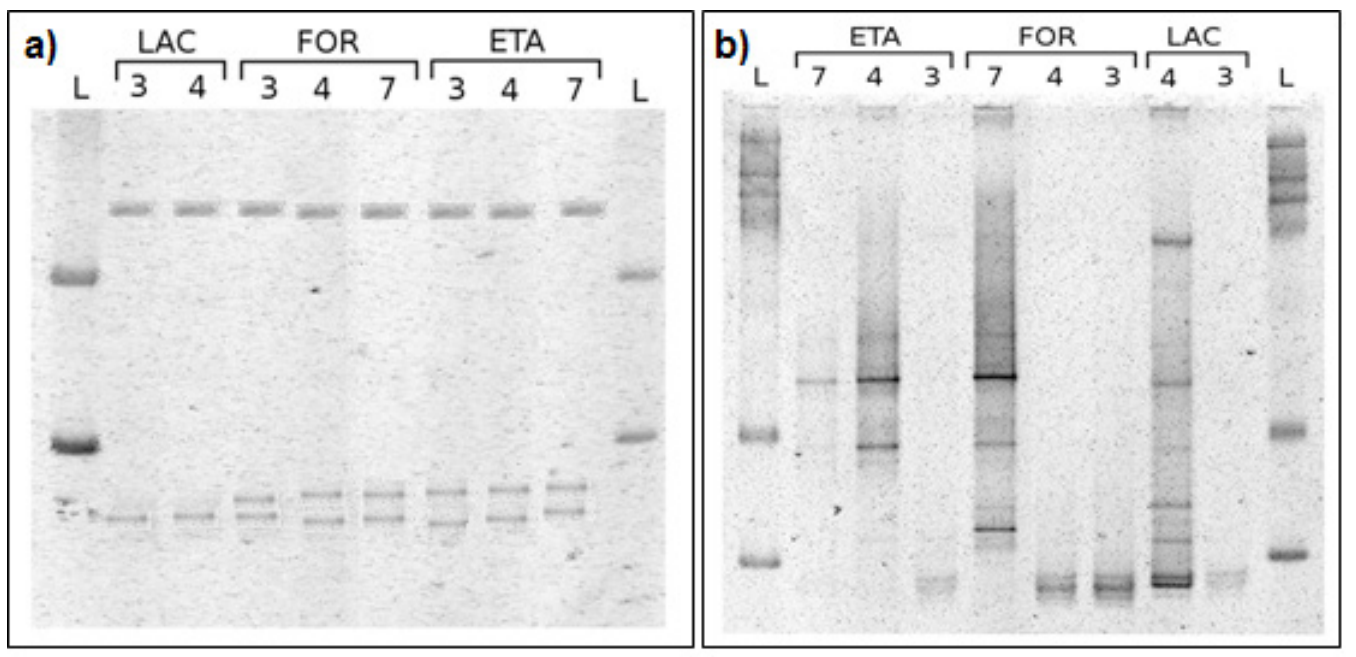

Figure 5. (a) Sulfate-reducing bacteria community profiles of the LAC, FOR, and ETA reactors under indicated initial $\mathrm{pH}$ conditions were compared using DGGE analysis. (b) Bacterial community profiles for the ETA, FOR, and LAC reactors under indicated initial $\mathrm{pH}$ conditions were compared using DGGE analysis. 
Table 5. Physical-chemical parameters for Phase 2 cultivation under neutral and acidic $\mathrm{pH}$ conditions.

\begin{tabular}{|c|c|c|c|c|c|c|c|c|c|}
\hline Parameter $^{\mathbf{a}}$ & $\begin{array}{l}\text { Reactor } \\
\text { LAC } 7 \\
\end{array}$ & $\begin{array}{l}\text { Reactor } \\
\text { LAC 3 }\end{array}$ & $\begin{array}{l}\text { Reactor } \\
\text { LAC } 4 \\
\end{array}$ & $\begin{array}{l}\text { Reactor } \\
\text { ETA } 7 \\
\end{array}$ & $\begin{array}{l}\text { Reactor } \\
\text { ETA 3 } \\
\end{array}$ & $\begin{array}{l}\text { Reactor } \\
\text { ETA 4 }\end{array}$ & $\begin{array}{c}\text { Reactor } \\
\text { FOR } 7 \\
\end{array}$ & $\begin{array}{c}\text { Reactor } \\
\text { FOR 3 } \\
\end{array}$ & $\begin{array}{c}\text { Reactor } \\
\text { FOR } 4 \\
\end{array}$ \\
\hline Initial $\mathrm{pH}^{\mathrm{b}}$ & $\begin{array}{l}7.41 \pm \\
0.10\end{array}$ & $\begin{array}{c}3.60 \pm \\
0.10\end{array}$ & $\begin{array}{l}5.12 \pm \\
0.10\end{array}$ & $\begin{array}{c}7.41 \pm \\
0.10\end{array}$ & $\begin{array}{c}5.97 \pm \\
0.10\end{array}$ & $\begin{array}{c}6.18 \pm \\
0.10\end{array}$ & $\begin{array}{c}7.05 \pm \\
0.10\end{array}$ & $\begin{array}{c}2.59 \pm \\
0.10\end{array}$ & $\begin{array}{c}4.15 \pm \\
0.10\end{array}$ \\
\hline Final $\mathrm{pH}$ & $\begin{array}{c}8.04 \pm \\
0.10\end{array}$ & $\begin{array}{c}3.68 \pm \\
0.10\end{array}$ & $\begin{array}{c}4.74 \pm \\
0.10\end{array}$ & $\begin{array}{c}7.70 \pm \\
0.10\end{array}$ & $\begin{array}{c}5.45 \pm \\
0.10\end{array}$ & $\begin{array}{c}6.75 \pm \\
0.10\end{array}$ & $\begin{array}{c}7.15 \pm \\
0.10\end{array}$ & $\begin{array}{c}2.78 \pm \\
0.10\end{array}$ & $\begin{array}{c}4.24 \pm \\
0.10\end{array}$ \\
\hline $\mathrm{COD} / \mathrm{SO}_{4}{ }^{2-}$ & $\begin{array}{c}1.08 \pm \\
0.09\end{array}$ & $\begin{array}{c}1.15 \pm \\
0.10\end{array}$ & $\begin{array}{l}1.27 \pm \\
0.12\end{array}$ & $\begin{array}{c}1.27 \pm \\
0.10\end{array}$ & $\begin{array}{c}0.95 \pm \\
0.09\end{array}$ & $\begin{array}{c}1.06 \pm \\
0.09\end{array}$ & $\begin{array}{c}1.20 \pm \\
0.11\end{array}$ & $\begin{array}{c}1.09 \pm \\
0.10\end{array}$ & $\begin{array}{c}1.02 \pm \\
0.08\end{array}$ \\
\hline $\begin{array}{l}\text { Maximum COD } \\
\text { removal (\%) }\end{array}$ & $25 \pm 3$ & $11 \pm 3$ & $22 \pm 3$ & $25 \pm 2$ & $5.5 \pm 3$ & $9.6 \pm 3$ & $42 \pm 2$ & $22 \pm 3$ & $30 \pm 3$ \\
\hline $\begin{array}{l}\text { Maximum } \\
\text { organic matter } \\
\text { removal }(\mathrm{mmol})\end{array}$ & $11.9 \pm 1.4$ & $4.9 \pm 1.3$ & $12.6 \pm 1.8$ & $14.2 \pm 2.6$ & $2.7 \pm 1.3$ & $4.9 \pm 1.6$ & $\begin{array}{c}156.2 \pm \\
8.3\end{array}$ & $66.2 \pm 9.4$ & $\begin{array}{c}101.1 \pm \\
10.0\end{array}$ \\
\hline $\begin{array}{l}\text { Stoichiometric } \\
\text { organic matter } \\
\text { value }(\mathrm{mmol})^{\mathrm{c}}\end{array}$ & $13.1 \pm 3.1$ & $7.9 \pm 2.6$ & $13.9 \pm 3.0$ & $15.7 \pm 3.7$ & $4.9 \pm 3.4$ & $3.6 \pm 2.9$ & $73.1 \pm 4.1$ & $\begin{array}{c}63.1 \pm \\
16.9\end{array}$ & $\begin{array}{c}84.4 \pm \\
25.6\end{array}$ \\
\hline $\begin{array}{c}\text { Maximum } \mathrm{SO}_{4}^{2-} \\
\text { removal }(\%)\end{array}$ & $44 \pm 11$ & $30 \pm 11$ & $43 \pm 9$ & $42 \pm 10$ & $18 \pm 13$ & $7 \pm 6$ & $34 \pm 12$ & $34 \pm 11$ & $39 \pm 10$ \\
\hline $\begin{array}{l}\text { Maximum } \mathrm{SO}_{4}^{2-} \\
\text { removal }(\mathrm{mmol})\end{array}$ & $19.6 \pm 4.6$ & $12.0 \pm 4.0$ & $20.8 \pm 4.5$ & $23.6 \pm 2.6$ & $7.3 \pm 5.2$ & $5.4 \pm 4.4$ & $18.3 \pm 6.1$ & $15.8 \pm 4.2$ & $21.0 \pm 5.3$ \\
\hline $\begin{array}{l}\mathrm{S}^{2-} \text { production } \\
(\mathrm{mmol})\end{array}$ & $16.0 \pm 0,4$ & $\begin{array}{c}0.19 \pm \\
0.07\end{array}$ & $\begin{array}{c}0.44 \pm \\
0.06\end{array}$ & $6.5 \pm 0.4$ & $\begin{array}{c}0.22 \pm \\
0.06\end{array}$ & $\begin{array}{l}1.16 \pm \\
0.09\end{array}$ & $2,5 \pm 0.3$ & $\begin{array}{c}0.69 \pm \\
0,09\end{array}$ & $\begin{array}{c}0.31 \pm \\
0.06\end{array}$ \\
\hline TVS (mg/l) & $1742 \pm 35$ & $\begin{array}{c}2.68 \pm \\
0.35\end{array}$ & $\begin{array}{c}1.86 \pm \\
0.31\end{array}$ & $370 \pm 36$ & $\begin{array}{c}2.19 \pm \\
0.33\end{array}$ & $\begin{array}{c}0.81 \pm \\
0.29\end{array}$ & $3738 \pm 43$ & $\begin{array}{c}3.26 \pm \\
0.37\end{array}$ & $\begin{array}{c}2.01 \pm \\
0.31\end{array}$ \\
\hline $\mathrm{MPN} / \mathrm{mL}$ & $4.0 \times 10^{3}$ & $\begin{array}{c}\text { Not } \\
\text { calculated }\end{array}$ & $\begin{array}{c}\text { Not } \\
\text { calculated }\end{array}$ & $6.8 \times 10^{3}$ & $\begin{array}{c}\text { Not } \\
\text { calculated }\end{array}$ & $\begin{array}{c}\text { Not } \\
\text { calculated }\end{array}$ & $1.2 \times 10^{3}$ & $\begin{array}{c}\text { Not } \\
\text { calculated }\end{array}$ & $\begin{array}{c}\text { Not } \\
\text { calculated }\end{array}$ \\
\hline
\end{tabular}

${ }^{a}$ The parameters were calculated using the arithmetic average of the duplicate reactors or the triplicate reactors (only for Reactor FOR 3 ). ${ }^{\mathrm{b}} \mathrm{pH}$ measured after inoculation of the reactors. ${ }^{c}$ The stoichiometric organic matter values were calculated using Reactions 1, 4, and 5 for the LAC, ETA, and FOR reactors, respectively; they indicate the organic matter removal that was expected based on the stoichiometry of these reactions.

bioreactors. Martins et al. (2009) reported a sulfate removal similar to this study using either lactate or ethanol as electron donors when studying acid mine drainage decontamination by metal-resistant SRB.

The experimental formate removal in the FOR 7 reactor was superior to the predicted organic matter removal based on the stoichiometry of Equation 5, probably because of formate consumption via pathways other than sulfate reduction such as methanogenesis. Although a COD/SO4-2- ratio of 1 yields methanogens that are uncompetitive and completely displaced by SRB, some studies have suggested the coexistence of methanogens and SRB not only in low sulfate environments, but also in the presence of nonlimiting sulfate concentrations (Hu et al., 2015, Raskin et al., 1996). However, as the formate activity coefficient varies according to its molar concentration from 0.7 to 0.9 (Bonner, 1988), a $\mathrm{COD} / \mathrm{SO}^{2-}$ ratio lower than expected may have been viable, causing lower electron availability for sulfate reduction.

The highest total concentration of volatile solids was observed in the FOR 7 reactor, indicating that the growth of a diverse microbial group is favored (Figure 5). In contrast, the ETA 7 reactor showed reduced microbial diversity when compared with the LAC 7 and FOR 7 reactors (Figure 5), which is probably due to a very specific SRB group capable of completely oxidizing ethanol (Rodriguez and Zaiat, 2011). The MPN quantification showed an SRB population of the same order of magnitude in the ETA, LAC, and FOR reactors, which was correlated with similar sulfate removal efficiencies obtained in the three reactors. However, the data obtained do not show a clear explanation for the decreased sulfide concentration in the liquid in ETA and FOR reactors, as the sulfide concentrations were below the expected stoichiometric values, suggesting the formation of compounds of intermediate oxidation state such as sulfite and/or thiosulfate, also seen in the Vilela et al. (2014) study.

The substitution of lactate with ethanol or formate as a carbon source in the Postgate $\mathrm{C}$ medium reduced the lag phase from 13 days to 3 and 2 days, respectively (Figure 6). Tsukamoto et al. (2004) and Zhou et al. (2015) also reported a smaller lag phase when ethanol was used as substrate for sulfate reduction. Lag phase reduction is important because it permits the faster growth of SRB, thus reducing the enrichment costs. This also proves that ethanol utilization during enrichment is more cost-effective than the usage of lactate. Ethanol was shown to be a better carbon source for enrichment at neutral conditions because the sulfate removal efficiency was maintained, with the occurrence of significant sulfide production, important for additional metal removal from acid mine drainage via sulfide precipitation during bioremediation. In addition, when a complete route is used to oxidize ethanol, alkalinization can be generated, allowing $\mathrm{pH}$ elevation in AMD (Oyekola et al., 2010). 


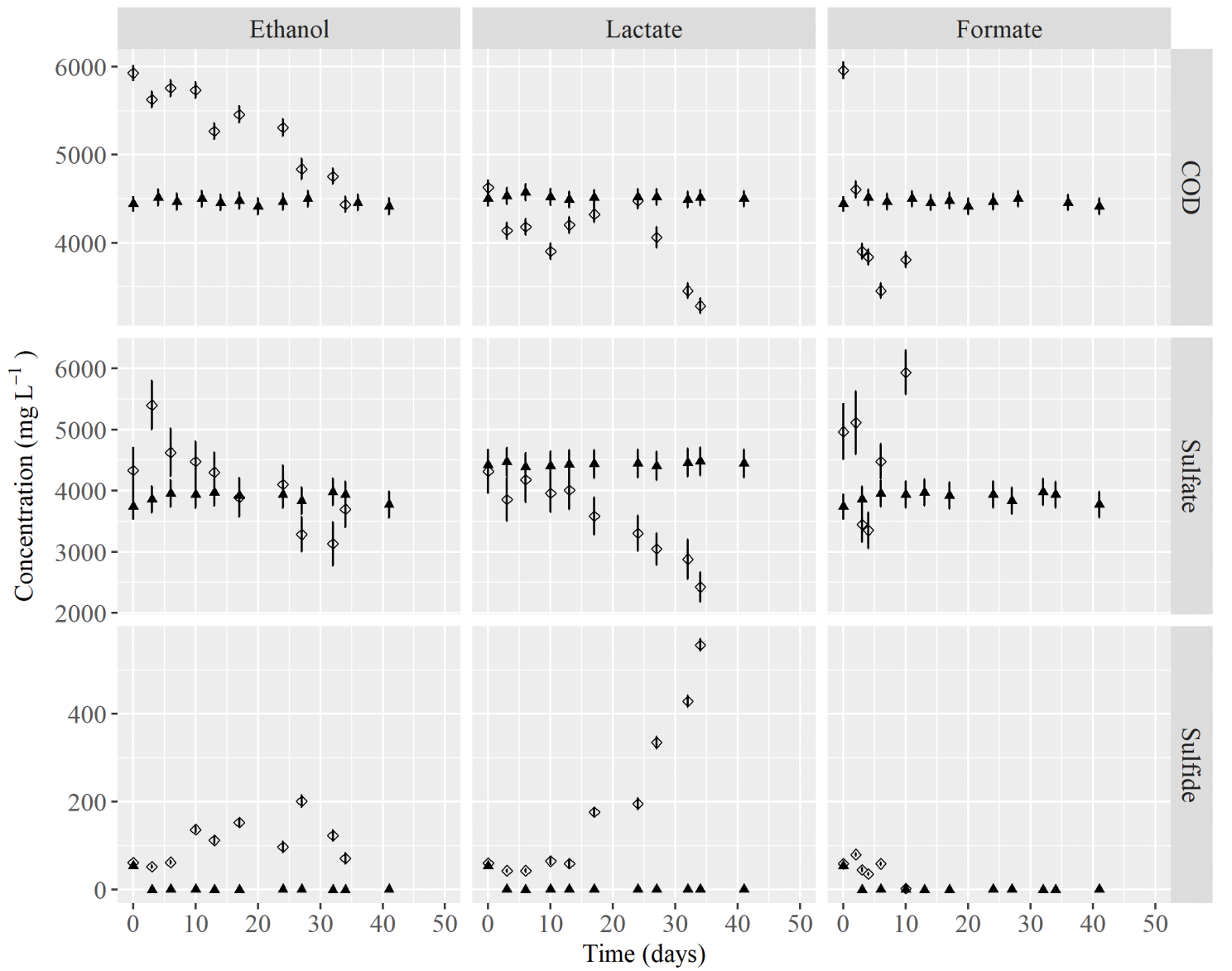

Figure 6. Performance of the LAC, ETA, and FOR reactors during the experiment in $\mathrm{pH} 7$ (Control ( $\mathbf{\Delta})$ and $\mathrm{pH} 7$ $(\diamond))$. The error bars correspond to $95 \%$ confidence interval.

The small cultivation period of the FOR 7 reactor is due to the oxidation of the enrichment medium after the 10-day experimental period. This can probably be explained by $\mathrm{H}_{2}$ production after the initial sulfate consumption, as observed by Martins et al. (2016). It is important to emphasize that, despite this inferior enrichment period, sulfate removal in the FOR 7 reactor $(\sim 18 \mathrm{mM})$ was close to that of the LAC 7 and ETA 7 reactors $(20 \mathrm{mM}$ and $24 \mathrm{mM}$, respectively). However, sulfide production drastically decreased (Table 5), making the use of formate for biomass enrichment less viable. This also confirms that ethanol is the better carbon source for SRB cultivation under neutral $\mathrm{pH}$ conditions, but adjustments in the $\mathrm{COD} /$ $\mathrm{SO}_{4}{ }^{2-}$ ratio, using values from 1.9 to 3 , need to be made to optimize the sulfide production (Vilela et al., 2014).

Besides, a large amount of sulfate and organic matter continued to be available in the bioreactors, and the final $\mathrm{pH}$ is not inhibitory as the sulfate reduction stopped in all reactors. This might have occurred due to the inhibitory effect of residual sulfate, which affects the operating $\mathrm{pH}$ and redox potential (Oyekola et al., 2010). The high residual sulfate concentration observed in LAC, ETA, and FOR reactors most likely increased the redox potential at the end of the experiment, not allowing the continual growth of SRB. In addition, the high sulfide concentration produced by the sulfate reduction process may have become toxic for ETA and LAC reactor species, as suggested by Kaksonen et al. (2004), causing the sulfate removal process to fail. According to Oyekola et al. (2010), lactate is reported to decrease sulfide toxicity, which could explain how the LAC reactor could support higher sulfide concentrations than expected (16 $\mathrm{mmol})$, compared to the ETA reactor $(6.5 \mathrm{mmol})$. Also, sulfide inhibition is species specific; in other words, the level of inhibition experienced by each system also depends on the dominant bacterial groups under different operating conditions. For the FOR reactor, organic matter continued to be consumed even when sulfate reduction ceased, showing that another group of microorganisms has become more competitive than SRB, leading other routes to prevail over the sulfidogenic one.

In acidic experiments, it was not possible to control the initial $\mathrm{pH}$, because it was significantly altered when sulfide and the inoculum was supplemented. Thus, it was not possible to compare the $\mathrm{pH}$ effect on each carbon source directly, especially because formate experiments were the only batch performed 
under acidic conditions. In addition, the low COD/ $\mathrm{SO}_{4}{ }^{2-}$ ratio used in all experiments may have affected the activity of SRB due to limited electron availability for sulfidogenesis, as also suggested by Vilela et al. (2014). As a result, sulfate removal efficiencies may not have been affected only by $\mathrm{pH}$ in the reactors studied.

The sulfate removal efficiency was not affected by the $\mathrm{pH}$ reduction in the FOR 3 and FOR 4 reactors under acidic conditions (34\% and 39\%, respectively; Table 5; Figure 7). This shows that formate is a possible carbon source for the enrichment process under acidic conditions. As Rodriguez and Zaiat (2011) showed, the sulfate concentration of an acid mine drainage site located in Poços de Caldas, Brazil (the same location as the sediment collected in the current study), was $\sim 16 \mathrm{mmol}$. The acidic FOR reactors were capable of removing sulfate around this order. Because formate contains only one carbon atom, it might be more readily oxidized by SRB than other substrates, such as lactate and ethanol (Rodriguez and Zaiat, 2011), which may have contributed to the maintenance of the sulfate removal efficiencies in low $\mathrm{pH}$ conditions. As low sulfide production was observed in these reactors, further analyses are necessary to prove that sulfate removal was effective even at low $\mathrm{pH}$. The formate feed reactor showed efficiencies consistent with other reported studies using a medium $\mathrm{COD} /$ sulfate ratio of $1.05 \pm 0.13$.

ETA experiments on acid tests were also performed close to neutrality ( $\mathrm{pH}$ around 6.0), due to the high elevation of the initial $\mathrm{pH}$ when sulfide and the inoculum were added to the medium. However, a small $\mathrm{pH}$ reduction in the ETA 3 and 4 reactors (from 7.4 to 6.0 ) caused the sulfate removal process to fail, based on the calculated errors, and very low sulfide production was observed. As such, it was not possible to prove that the sulfate reduction process occurred. In addition, the low $\mathrm{COD} / \mathrm{SO}_{4}{ }^{2-}$ ratio used $(1.00 \pm$ 0.12 ), may have also affected the process efficiency, as according to Vilela et al. (2014), a $\mathrm{COD} / \mathrm{SO}_{4}{ }^{2-}$ ratio of approximately 1.9 is ideal for incomplete ethanol oxidizers to promote an efficient sulfidogenic process. Najib et al. (2017) also reported the effect of the COD/ sulfate ratio and $\mathrm{pH}$ reduction from neutral 7 to 6 on an ethanol feed reactor. When $\mathrm{COD} /$ sulfate $\sim 2$ was used, efficiencies of $96 \%$ were obtained, likewise reduced to $39 \%$ for a $\mathrm{COD} / \mathrm{sulfate}$ ratio of 0.5 . The same occurred with the $\mathrm{pH}$ reduction from 7 to 6 , causing the efficiency to decline to $36 \%$ in limiting substrate

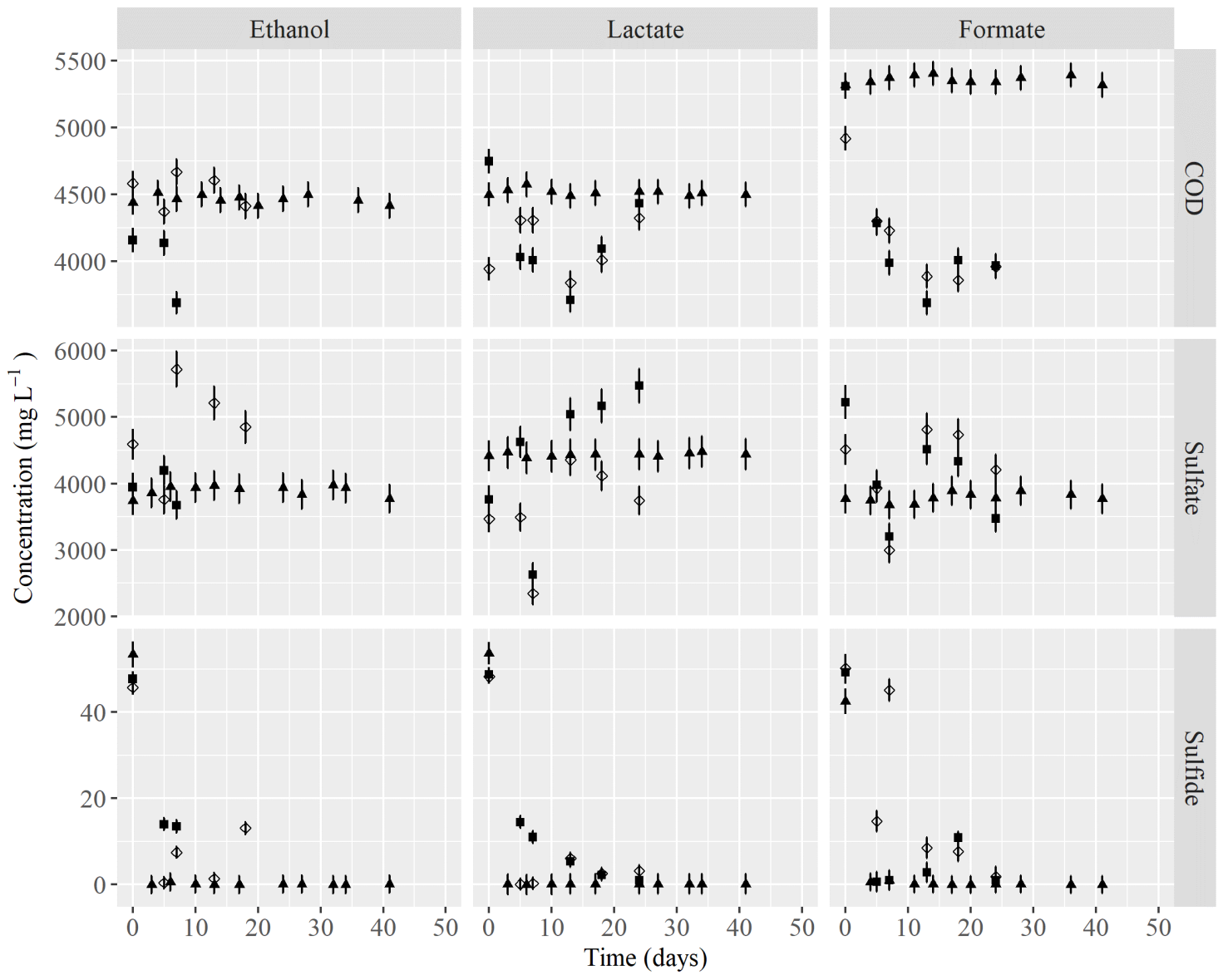

Figure 7. Performance of the LAC, ETA, and FOR reactors during the acidic $\mathrm{pH}$ experiment (Control ( $\bullet$ ), $\mathrm{pH} 3$ $(\diamond)$ e $\mathrm{pH} 4(\square))$. The error bars correspond to $95 \%$ confidence interval. 
conditions. Thus, the limiting electron availability might have not favored the use of ethanol for sulfate reduction by $\mathrm{SRB}$, causing fermentative bacteria and other microorganisms to compete with SRB for ethanol, as reported by Sun et al. (2016). As it was not possible to maintain the initial $\mathrm{pH}$ around 3 and 4 for ETA reactors, a complementary study is necessary to analyze the potential use of this carbon source as substrate for autochthonous SRB in low $\mathrm{pH}$.

The sulfate removal efficiency with lactate as a carbon source was affected in reactor LAC 3 (reduced to $30 \%)$ and maintained in reactor LAC $4(43 \%)$. Because the sulfate removal efficiency was reduced due to $\mathrm{pH}$ modification, lactate is not an ideal carbon source for enrichment at inoculation $\mathrm{pH}$ values lower than 3.6. For inoculation $\mathrm{pH} \sim 5$, however, the observed sulfate removal ( $\sim 21 \mathrm{mmol})$ was significant based on the AMD sulfate concentration $(\sim 16 \mathrm{mmol})$. Sulfate removal values at $\mathrm{pH} 5(41 \%)$ and $\mathrm{pH} 7$ (44\%), similar to that in this study, were demonstrated by Verma et al. (2015). At pH 5, Jong and Parry (2006) also obtained sulfate reduction values similar to that in this experiment (43\%). However, at $\mathrm{pH} 3$, they determined values $(6 \%)$ lower than the ones found in this study. Jong and Parry (2006) also observed that SRB activity decreased proportionally with increasing undissociated lactate concentration, as undissociated organic acids are able to diffuse across the cell membrane at low $\mathrm{pH}$ and prevent the bacterial cell from maintaining a membrane potential and proton motive force, causing an inhibitory effect on SRB activity. Therefore, it is also important to remember that very low sulfide production was observed on LAC reactors, indicating that more information is necessary to prove that the sulfate removal process was stabilized.

Based on the stoichiometry, reactors ETA 3, LAC 3 , and LAC 4 had lower experimental organic matter removal than expected, likely because of acetate accumulation due to incomplete oxidation of organic matter by SRB, as reported by Bertolino et al. (2012). This acetate accumulation may also be caused by the $\mathrm{pH}$ reduction in reactors ETA 3 and LAC 4, as acetate can also be found in acetic acid formed in these reactors (Sánchez-Andrea et al., 2014). Sánchez-Andrea et al. (2013), in a similar study using acidophilic sulfatereducing bacteria from Tinto River sediments, also reported acetate accumulation in all the enrichments performed and identified that the enrichments for sulfate-reducing microorganisms were dominated by the Desulfotomaculum species (Sánchez-Andrea et al. 2012).

The optimum $\mathrm{pH}$ value for the growth of most known SRB ranges between 5 and 9 (Postgate, 1984), which also explains the reduction in the sulfate removal efficiency in the acidic LAC and ETA reactors. A low $\mathrm{pH}$ reflects more energy investment in pumping protons across the cell membrane, thereby increasing the energy expenditure. However, the existence of acidotolerant and acidophilic SRB, such as the Desulfotomaculum species found in this study, identified in the AUT community in Phase 1 (Figure 4), and resistant to $\mathrm{pH}$ reduction in Phase 2 (Figure 5), provides the possibility of treating acidic waters directly, without previous effluent neutralization, thereby reducing the cost. Even though a decrease in bacterial biodiversity was noted in acidic conditions compared to neutral $\mathrm{pH}$ (Figure 5), the reactor performance in sulfate removal may not be adversely affected, as also demonstrated by Zhao et al. (2016), who reported efficiencies higher than $90 \%$ in acidic $\mathrm{pH}$ of 2.5 , and $\mathrm{COD} /$ sulfate ratio $\sim 2$. However, Zhao et al. (2016) used a non-autochthonous biomass and compartmentalized bioreactor that can limit, to a great extent, the exposure of the biomass to adverse environmental conditions, such as low-pH shock. This can help explain the lower efficiencies that were obtained, considering the limiting $\mathrm{COD} /$ sulfate ratio used in this study. It is important to consider that SRB, even when present uniformly in all studied bioreactors in neutral and acidic $\mathrm{pH}$, may have their activity reduced with $\mathrm{pH}$ modification. With this in consideration, the sulfate reduction process can be efficient without $\mathrm{pH}$ control, as long as this process generates alkalinity, allowing the $\mathrm{pH}$ to increase (Sánchez-Andrea et al. 2014). The activity of SRB might have been affected in the studied bioreactors because the $\mathrm{pH}$ did not increase. Church et al. (2007) also observed no $\mathrm{pH}$ elevation during the enrichment of extremophile SRB, and it probably occurred because the sulfidogenic process was not favored at low $\mathrm{pH}$, so perhaps other routes were used by SRB that do not generate carbonate.

Low sulfide production was observed in all reactors cultivated under acidic conditions (Table 5 and Figure 7), likely because this condition does not favor sulfidogenic species. However, control reactors are present in Figure 7, suggesting that sulfide drops to zero after medium reduction and, thus, a small amount of sulfidogenic activity was observed in all reactors. Alternative pathways for sulfate removal and COD consumption may have been used by SRB, resulting in different reaction products, such as elemental sulfur (visually observed based on the formation of a white precipitate, thiosulfate and sulfite, as reported in Lee et al. (2014). Low sulfide production was also observed by Church et al. (2007), with a value of $0.015 \mathrm{mmol}$ found during enrichment of sediments from an acid mine using a modified Postgate $\mathrm{C}$ medium and a $\mathrm{pH}$ around 4. They noted the presence of elemental sulfur in the low-pH experiments, instead of sulfide, due to the higher stability field for elemental sulfur in low$\mathrm{pH}$ microcosms. They also reported that sulfur might not be a direct metabolic product in low $\mathrm{pH}$. The 
toxicity of $\mathrm{H}_{2} \mathrm{~S}$, the predominant form of sulfide at $\mathrm{pH}$ values lower than 7 , could be an impetus for different pathway utilization by SRB (Bijmans et al., 2008). Also, according to Koschorreck (2008), it is a common adaptation strategy of anaerobic bacteria to change their metabolic route at a low $\mathrm{pH}$ in order to avoid the build-up of toxic concentrations of organic acid. However, further analyses are necessary to prove that alternative pathways were used by SBR and to prove the effectiveness of the sulfate reduction process.

Different bacterial communities were observed in the studied reactors (Figure 5b), showing that the carbon source and initial $\mathrm{pH}$ considerably affect the microbial population, even when the same biomass is used as inoculum, as reported by Zhou et al. (2015). According to Sánchez-Andrea et al. (2014), the pH can affect the activity of different microorganisms, whereas the substrate can affect the complexity of these communities, thus having an important effect on the microbial community composition of a reactor. Uniformity of SRB diversity was observed in the SRB groups of all reactors, probably due to the low diversity of the AUT inoculum used, as shown in Figure 3. Besides, it was not possible to prove the establishment of an effective sulfate removal process. Figure 5a shows that autochthonous populations selected under different enrichment conditions were present in the bioreactors. Thus, even with the difficulty of using an autochthonous group to treat AMD in acidic conditions, AUT biomass was resistant to acidic $\mathrm{pH}$, revealing a possible potential for autochthonous SRB but also indicating that more investigation is necessary to prove their effectiveness in bioremediation of AMD.

The acidic resistance of the AUT culture can probably be explained by the capability of these microorganisms to face the proton motive force across the cell membrane that can drive energy-dependent processes to promote $\mathrm{pH}$ homeostasis, as mentioned in Florentino (2017). Many strategies can be used by acidophilic and acidotolerant SRB to maintain physiological $\mathrm{pH}$ despite external acidic conditions, such as the utilization of specific transporters and enzymes for proton export (e.g., proton ATPases, antiporters, and symporters), adoption of particular permeability properties, incremental changes in the buffer capacity to sequester or release protons based on pH shifts, and enhancement of positive surface charges. These microorganisms generally have an impermeable cell membrane or low membrane fluidity that restricts the proton influx to the cytoplasm (Florentino, 2017).

Another important strategy used by the Desulfotomaculum species is spore formation, which enables them to survive under unfavorable environmental conditions. As cited by O'Sullivan et al. (2015), bacterial endospores can withstand multiple environmental stress conditions, such as extremes in $\mathrm{pH}$ and, thus, are remarkable survival systems that are able to persist over geological timescales. Although the AUT culture can survive under extreme $\mathrm{pH}$ conditions found in acid mine drainage, this condition prohibits the growth of the SRB population (Martins et al., 2011), which indicates the importance of the enrichment process in the establishment of an autochthonous sulfidogenic population capable of acid mine drainage treatment, even under acidic conditions. Giloteaux et al. (2013) also reported that SRB can survive in microenvironments associated with particles that provide protection from surrounding acidity and oxygen, enabling the tolerance of SRB to acidic conditions. According to Jing and Kjellerup (2017), microniches with elevated $\mathrm{pH}$ can form around SRB. Microniches, as defined in microbial ecology, are small areas with microbial actions that differ from those of the surrounding bulk soil or sediment habitat.

Sulfidogenic species were not favored under low $\mathrm{pH}$ conditions; low sulfide production was observed in all acidic experiments. However, these species were favored under neutral conditions; high sulfide production was observed when ethanol and lactate were the carbon sources. Because ethanol is a cost-effective carbon source and favors sulfidogenic species, the best alternative for enrichment of autochthonous SRB is the use of ethanol.

After the inoculation of this community in the sulfidogenic bioreactor used for acid mine drainage treatment, $\mathrm{pH}$ reduction using ethanol is possible, as reported by Bai et al. (2013) and Martins et al. (2011). Because the autochthonous SRB were resistant to acidic conditions and the DGGE analyses proved their presence in all reactors, gradual $\mathrm{pH}$ reduction will probably not reduce the sulfate removal efficiencies.

\section{CONCLUSIONS}

This study showed that the sulfate removal and sulfide production of the selected AUT population were similar to that of the N-AUT population after an acclimation period, showing that the AUT culture can have an interesting potential use for local acid mine drainage treatment. However, it was noted that the N-AUT community was capable of using lactate more quickly, avoiding an extended lag phase, also due to the identified species of Desulfovibrio genus present in this bioreactor, known for their capacity to grow faster when using lactate than other species. The N-AUT and AUT cultures had distinct community structures, both in the domain Bacteria and SRB groups. Low diversity was observed for the SRB group in the AUT reactor compared with that of the N-AUT reactor, probably due to the spore-forming capacity of the Desulfotomaculum species that allows their survival in 
unfavorable conditions such as AMD and also causes the need of a lag phase for medium adaptation.

It is important to emphasize that the $\mathrm{COD} /$ sulfate ratio used, with a medium value of $1.14 \pm 0.10$, is a limiting condition for the sulfate reduction process, also contributing to efficiencies of sulfate removal lower than $70 \%$. Therefore, based on similar sulfate removal efficiencies, effective sulfide production, and lag phase reduction, it was possible to infer that ethanol is a viable and low-cost alternative substitute for lactate as an enrichment carbon source under neutral $\mathrm{pH}$ conditions. Formate showed similar sulfate removal efficiency; however, it is not an effective electron donor for sulfate reduction under neutral conditions and adjustments of the COD/sulfate ratio are necessary to optimize sulfide production when this carbon source is used.

Sulfate removal efficiencies for the electron donors formate (inoculation $\mathrm{pH}$ of 3 and 4) and lactate (inoculation $\mathrm{pH}$ of 5) were similar in low $\mathrm{pH}$ to those obtained in neutral $\mathrm{pH}$ conditions used for enrichment. At low $\mathrm{pH}$, a combination of organic acids accumulation and lower carbonate production probably hidered $\mathrm{pH}$ elevation, which may have inhibited the sulfidogenic route outcompetition for the electron donor oxidation. In addition, complementary data are necessary to corroborate the hypothesis that other intermediate routes were used by SRB, producing thiosulfate, sulfur, or sulfite. Carbon source modification and $\mathrm{pH}$ reduction to acidic levels significantly changed the bacterial diversity. Similar diversity was observed for the SRB group, confirming the presence and resistance of this community under acidic conditions.

According to the obtained results, the autochthonous SRB cultures presented potential for AMD bioremediation. However, this initial study is important due to the complexity of autochthonous microorganisms and represents a fundamental study of the enrichment process of extremophiles, raising the possibility of stabilizing an enrichment medium for their growth and application to AMD treatment.

\section{ACKNOWLEDGMENTS}

The authors are very grateful to the Fundação de Amparo à Pesquisa de Minas Gerais (FAPEMIG) for providing research funding (Process Number TEC - APQ-02894-14) and the Universidade Federal de Alfenas (UNIFAL) for granting a Pib-Pós scholarship.

\section{NOMENCLATURE}

$\begin{array}{ll}\text { AMD } & \text { Acid Mine Drainage } \\ \text { AUT } & \text { Autochthonous } \\ \text { COD } & \text { Chemical Oxygen Demand }\left(\mathrm{mg} \cdot \mathrm{L}^{-1}\right) \\ \text { Control } & \text { Control Reactor }\end{array}$

$\begin{array}{ll}\text { DGGE } & \begin{array}{l}\text { Denaturing gradient gel } \\ \text { electrophoresis }\end{array} \\ \text { DNA } & \begin{array}{l}\text { Deoxyribonucleic acid } \\ \text { Ethanol feed reactor }\end{array} \\ \text { ETA } & \text { Formate feed reactor } \\ \text { FOR } & \text { Lactate feed reactor } \\ \text { LAC } & \text { Most Probable Number } \\ \text { MPN } & \text { Non-autochthonous } \\ \text { N-AUT } & \text { Polymerase chain reaction } \\ \text { PCR } & \text { Sulfide }\left(\mathrm{mg} \cdot \mathrm{L}^{-1}\right) \\ \mathrm{S}^{2-} & \text { Sulfate }\left(\mathrm{mg} \cdot \mathrm{L}^{-1}\right) \\ \mathrm{SO}_{4}^{2-} & \text { Sulfate-reducing bacteria } \\ \text { SRB } & \text { Total Volatile Solids }\left(\mathrm{mg} \cdot \mathrm{L}^{-1}\right) \\ \text { TVS } & \end{array}$

\section{REFERENCES}

Altun, M., Sahinkaya, E., Durukan, I., Bektas, S., Komnitsas, K. Arsenic removal in a sulfidogenic fixed-bed column bioreactor, J Hazard Mater, 269, 31-37 (2014). https://doi.org/10.1016/j. jhazmat.2013.11.047

APHA, Standard methods for the examination of water and wastewater. American Public Health Association, New York (2012).

Azubuike, C.C., Chikere, C.B., Okpokwasili, G.C. Bioremediation techniques-classification based on site of application: principles, advantages, limitations and prospects, World J Microbiol Biotechnol, 32, 180 (2016). https://doi.org/10.1007/ s11274-016-2137-x

Bai, H., Kang, J., Quan, H., Han, Y., Sun, H., Feng, Y. Treatment of acid mine drainage by sulfate reducing bacteria with iron in bench scale runs, Bioresour Technol, 128, 818-822 (2013). https:// doi.org/10.1016/j.biortech.2012.10.070

Bekmezcia, O.K., Ucara, D., Kaksonen, A.H., Sahinkayaa, E. Sulfidogenic biotreatment of synthetic acid mine drainage and sulfide oxidation in anaerobic baffled reactor, J Hazard Mater, 189, 670-676 (2011). https://doi.org/10.1016/j. jhazmat.2011.01.087

Bertolino, S.M., Melgaço, L.A., Sá, R.G., Leão, V.A. Comparing lactate and glycerol as a singleelectron donor for sulfate reduction in fluidized bed reactors, Biodegrad, 25, 719-733 (2014). https:// doi.org/10.1007/s10532-014-9694-1

Bertolino, S.M., Rodrigues, I.C.B., Guerra-Sá, R., Aquino, S.F., Leão, V.A. Implications of volatile fatty acid profile on the metabolic pathway during continuous sulfate reduction, J Environ Manage, 103, 15-23 (2012). https://doi.org/10.1016/j. jenvman.2012.02.022

Bijmans, M.F.M., Dopson, M., Ennin, F., Lens, P.N.L., Buisman, C.J.N. Effect of sulfide removal on sulfate reduction at ph 5 in a hydrogen fed gas-lift bioreactor, J Microbiol Biotechnol, 18, 1809-1818 (2008). https://doi.org/10.4014/jmb.0800.109 
Bonner, O.D. Osmotic and activity coefficients of the sodium salts of formic, acetic and propionic acids, J Solution Chen, 17, 999-1002 (1988). https://doi. org/10.1007/BF00649743

Cabrera, G., Perez, R., Gomez, J.M., Abalos, A., Cantero, D. Toxic effects of dissolved heavy metals on Desulfovibrio vulgaris and Desulfovibrio sp. Strains, J Hazard Mater 135, 40-46 (2005). https:// doi.org/10.1016/j.jhazmat.2005.11.058

Cao, J., Zhang, G., Mao, Z., Li, Y., Fang, S., Yang, C., Influence of electron donors on the growth and activity of sulfate-reducing bacteria, International Journal of Mineral Processing, 106109, 58-64 (2012). https://doi.org/10.1016/j. minpro.2012.02.005

Ceccherini, M.T., Ascher, J., Agnelli, A., Borgogni, F., Pantani, O.L., Pietramellara, G. Experimental discrimination and molecular characterization of the extracellular soil DNA fraction, Antonie van Leeuwenhoek, 96, 653-657 (2009). https://doi. org/10.1007/s10482-009-9354-3

Cheung, K.H., Gu, J. Reduction of chromate $\left(\mathrm{CrO}_{4}^{2-}\right.$ ) by an enrichment consortium and an isolate of marine sulfate-reducing bacteria, Chemosphere, 52, 1523-1529 (2003). https://doi.org/10.1016/ S0045-6535(03)00491-0

Church, C.D., Wilkin, R.T., Alpers, C.N., Rye, R.O., McCleskey, R.B. Microbial sulfate reduction and metal attenuation in $\mathrm{pH} 4$ acid mine water, Geochemical Transact, 8, 10 (2007). https://doi. org/10.1186/1467-4866-8-10

Dar, S.A., Kleerebezem, R., Stams, A.J.M., Kuenen, J.G., Muyzer, G. Competition and coexistence of sulfate-reducing bacteria, acetogens and methanogens in a lab-scale anaerobic bioreactor as affected by changing substrate to sulfate ratio, Appl Microbiol Biotechnol. 78, 1045-1055 (2008). https://doi.org/10.1007/s00253-008-1391-8

Florentino, A.P., Physiology and application of sulfurreducing microorganisms from acid environments. Ph.D. Thesis, Wageningen University (2017).

Geets, J., Borremans, B., Diels, L., Springael, D., Vangronsveld, J., an der Lelie, D., Vanbroekhoven, K. DsrB gene-based DGGE for community and diversity surveys of sulfate-reducing bacteria, Journal of Microbiological Methods, 66, 194-205 (2006). https://doi.org/10.1016/j.mimet.2005.11.002

George, J., Purushothaman, C.S., Shouche, S.Y. Isolation and characterization of sulphate-reducing bacteria Desulfovibrio vulgaris from Vajreshwari thermal springs in Maharashtra, India, World J Microbiol Biotechnol, 24, 681-685 (2008). https:// doi.org/10.1007/s11274-007-9524-2

Giloteaux, L., Duran, R., Casiot, C., Bruneel, O., ElbazPoulichet, F., Goñi-Urriza, M. Three-year survey of sulfate-reducing bacteria community structure in Carnoulès acid mine drainage (France), highly contaminated by arsenic, FEMS Microbiol Ecol, 83, 724-737 (2013). https://doi.org/10.1111/15746941.12028

Hwang, S.K., Jho, E.H. Heavymetal and sulfate removal fromsulfate-rich synthetic mine drainages using sulfate reducing bacteria, Science of the Total Environment, 635, 1308-1316 (2018). https://doi. org/10.1016/j.scitotenv.2018.04.231

Heuer, H., Krsek, M., Baker, P., Smalla, K., Wellington, E.M. Analysis of actinomycete communities by specific amplification of genes enCOD ing $16 \mathrm{~S}$ rRNA and gel-electrophoretic separation in denaturing gradients, Appl Environ Microbiol, 63, 3233-3241 (1997).

Hosokawa, R., Nagai, M., Morikawa, M., Okuyama, H. Autochthonous bioaugmentation and its possible application to oil spills, World J Microbiol Biotechnol, 25, 1519-1528 (2009). https://doi. org/10.1007/s11274-009-0044-0

Hu, Y., Jing, Z., Sudo, Y., Niu, Q., Du, J., Wu, J., $\mathrm{Li}, \mathrm{Y}$. Effect of influent $\mathrm{COD} / \mathrm{SO}_{4}{ }^{2-}$ ratios on UASB treatment of a synthetic sulfate-containing wastewater, Chemosphere, 130, 24-33 (2015). https://doi.org/10.1016/j.chemosphere.2015.02.019

Jing, R., Kjellerup, B.V. Biogeochemical cycling of metals impacting by microbial 2 mobilization and immobilization, J of Environ Sci, 66, 146-154 (2017). https://doi.org/10.1016/j.jes.2017.04.035

Jong, T., Parry, D.L. Microbial sulfate reduction under sequentially acidic conditions in an upflow anaerobic packed bed bioreactor, Water Res, 40, 2561-2571 (2006). https://doi.org/10.1016/j. watres.2006.05.001

Kaksonen, A.H., Franzmann, P.D., Puhakka, J.A. Effects of Hydraulic Retention Time and Sulfide Toxicity on Ethanol and Acetate Oxidation in Sulfate-Reducing MetalPrecipitating FluidizedBed Reactor, Biotechnology and Bioengineering, 86, 332-343 (2004). https://doi.org/10.1002/ bit.20061

Kaksonen, A.H., Plumb, J.J., Robertson, W.J., Riekkola-Vanhanen, M., Franzmann, P.D., Puhakka, J.A. The performance, kinetics and microbiology of sulfidogenic fluidized-bed treatment of acidic metal- and sulfate-containing wastewater, Hydrometall, 83, 204-213 (2006). https://doi.org/10.1016/j.hydromet.2006.03.025

Koschorreck, M. Microbial sulphate reduction at a low pH, FEMS Microbiol Ecol, 64, 329-342 (2008). https://doi.org/10.1111/j.1574-6941.2008.00482.x

Kuever, J., Rainey, F.A., Hippe, H. Description of Desulfotomaculum sp. Groll as Desulfotomaculum gibsoniae sp. Nov, Int J Syst Bacteriol, 49, 18011808 (1999). https://doi.org/10.1099/0020771349-4-1801 
Lee, D., Liu, X., Weng, H. Sulfate and organic carbon removal by microbial fuel cell with sulfate-reducing bacteria and sulfide-oxidising bacteria anodic biofilm, Bioresour Technol, 156, 14-19 (2014). https://doi.org/10.1016/j.biortech.2013.12.129

Lee, P.Y., Costumbrado, J., Hsu, C., Kim, Y.H. Agarose Gel Electrophoresis for the Separation of DNA Fragments. J Vis Exp., 62, 1-5 (2012). https://doi. org $/ 10.3791 / 3923$

Lopez, M.V., Dias, A.C.F., Fasanella, C.C., Durrer, A., Melo, I.S., Kuramae, E.E., Andreote, F.D. Sulphuroxidizing and sulphate-reducing communities in Brazilian mangrove sediments, Environ Microbiol, 16, 845-855 (2014). https://doi.org/10.1111/14622920.12237

Lu, J., Chen, T., Wua, J., Wilson, C.P., Hao, X., Qian, J. Acid tolerance of an acid mine drainage bioremediation system based on biological sulfate reduction, Bioresour Technol, 102, 10401-10406 (2011). https:// doi.org/10.1016/j.biortech.2011.09.046

Lu, X., Zhen, G., Ni, J., Hojo, T., Kubota, K., $\mathrm{Li}, \mathrm{Y}$., Effect of influent $\mathrm{COD} / \mathrm{SO}_{4}{ }^{2-}$ ratios on biodegradation behaviors of starch wastewater in an upflow anaerobic sludge blanket (UASB) reactor, Bioresource Technology, 214, 175-183 (2016). https://doi.org/10.1016/j.biortech.2016.04.100

Luptakova, A., Kusnierova, M. Bioremediation of acid mine drainage contaminated by SRB, Hydrometall 77, 97-102 (2005). https://doi.org/10.1016/j. hydromet.2004.10.019

Martins, M., Faleiro, M.L., Barros, J.R., Veríssimo, A.R., Barreiros, M.A., Costa, M.C. Characterization and activity studies of highly heavy metal resistant sulphate-reducing bacteria to be used in acid mine drainage decontamination, J Hazard Mater, 166, 706-713 (2009). https://doi.org/10.1016/j. jhazmat.2008.11.088

Martins, M., Mourato, C., Morais-Silva, F.O., Rodrigues-Pousada, C., Voordouw, G., Wall, J.D., Pereira, I.A. Electron transfer pathways of formate-driven $\mathrm{H}_{2}$ production in Desulfovibrio, Appl Microbiol Biotechnol, 100, 8135-46, (2016). https://doi.org/10.1007/s00253-016-7649-7

Martins, M., Santos, E.S., Faleiro, M.L., Chaves, S., Tenreiro, R., Barros, R.J., Barreiros, A., Costa, M.C. Performance and bacterial community shifts during bioremediation of acid mine drainage from two Portuguese mines, Int Biodeterior Biodegrad, 65, 972-981 (2011). https://doi.org/10.1016/j. ibiod.2011.07.006

Meyer, B., Kuever, J., Molecular Analysis of the Diversity of Sulfate-Reducing and SulfurOxidizing Prokaryotes in the Environment, Using aprA as Functional Marker Gene, Applied and Environmental Microbiology, 73, 7664-7679 (2007). https://doi.org/10.1128/AEM.01272-07
Miller, J.N., Miller, J.C. Statistics and chemometrics for analytical chemistry. Pearson Education Limited. England (2010).

Muyzer, G., Stams, A.J.M. The ecology and biotechnology of sulphate-reducing bacteria, Nat Rev Microbiol, 6, 441-454 (2008). https://doi. org/10.1038/nrmicro1892

Nagpal, S., Chuichulcherm, S., Livingston, A., Peeva, L. Ethanol Utilization by Sulfate-Reducing Bacteria: An Experimental and Modeling Study, Biotechnology and Bioengineering, 70, 533-543 (2000). https://doi. org/10.1002/1097-0290(20001205)70:5\%3C533::AIDBIT8\%3E3.3.CO;2-3

Najib, T., Solgi, M., Farazmand, A., Heydarian, S.M., Nasernejad, B. Optimization of sulfate removal by sulfate reducing bacteria using response surface methodology and heavy metal removal in a sulfidogenic UASB reactor, Journal of Environmental Chemical Engineering, 5, 3256-3265 (2017). https://doi.org/10.1016/j.jece.2017.06.016

Oyekola, O. O., van Hille, R.O., Harrison, S.T.L. Kinetic analysis of biological sulphate reduction using lactate as carbon source and eletron donor: Effect of sulphate concentration, Chemical Engineering Science, 65, 4771-4781, (2010). https://doi.org/10.1016/j.ces.2010.05.014

O’Sullivan, L.A., Roussel, E.G., Weightman, A.J., Webster, G., Hubert, C.R.J., Bell, E., Head, I., Sass, H., Parkes, J.R. Survival of Desulfotomaculum spores from estuarine sediments after serial autoclaving and high-temperature exposure, The ISME Journal, 9, 922-933 (2015). https://doi. org/10.1038/ismej.2014.190

Postgate, J.R. The sulphate reducing bacteria. Cambridge University Press, Cambridge (1984).

R Core Team (2018). R: A language and environment for statistical computing. $\mathrm{R}$ Foundation for Statistical Computing, Vienna, Austria. URL https://www.R-project.org/.

Raskin, L., Rittmann, B.E., Stahl, D.A. Competition and Coexistence of Sulfate-Reducing and Methanogenic Populations in Anaerobic Biofilms, Applied and Environmental Microbiology, 62, 3847-3857 (1996).

Rampinelli, L.R., Azevedo, R.D., Teixeira, M.C., Guerra-Sa, R., Leão, V.A. A sulfate-reducing bacterium with unusual growing capacity in moderately acidic conditions, Biodegrad, 19, 613619 (2008). https://doi.org/10.1007/s10532-0079166-y

Rodriguez, R.P., Zaiat, M. Influence of carbon source and inoculum type on anaerobic biomass adhesion on polyurethane foam in reactors fed with acid mine drainage, Bioresour Technology, 102, 5060-5065 (2011). https://doi.org/10.1016/j. biortech.2011.01.084 
Rodriguez, R.P., Oliveira, G.H.D., Raimundi, I.M., Zaiat M. Assessment of a UASB reactor for the removal of sulfate from acid mine water, International Biodeterioration \& Biodegradation, 74, 48-53 (2012). https://doi.org/10.1016/j.ibiod.2012.07.012

Sahinkaya, E., Gunes, F.M., Ucar, D., Kaksonen, A.H. Sulfidogenic fluidized bed treatment of real acid mine drainage water, Bioresour Technol, 102, 683-689 (2011). https://doi.org/10.1016/j. biortech.2010.08.042

Sahinkaya, E., Yucesoy, Z. Biotreatment of acidic zinc- and copper-containing wastewater using ethanol-fed sulfidogenic anaerobic baffled reactor, Bioprocess Biosyst Eng, 33, 989-997 (2010). https://doi.org/10.1007/s00449-010-0423-9

Sánchez-Andrea, I., Ojeda, P.R., Amils, R., Sanz, J.L. Screening of anaerobic activities in sediments of an acidic environment: Tinto River, Extremophiles, 16, 829-839 (2012). https://doi.org/10.1007/ s00792-012-0478-4

Sánchez-Andrea, I., Sanza, J.L., Bijmansc, M.F.M., Stams, A.J.M. Sulfate reduction at low ph to remediate acid mine drainage, Journal of Hazardous Materials, 269, 98-109 (2014). https:// doi.org/10.1016/j.jhazmat.2013.12.032

Sánchez-Andrea, I., Stams, A.J.M., Amils, R., Sanz, J.L. Enrichment and isolation of acidophilic sulfatereducing bacteria from Tinto River sediments, Environmental Microbiology Reports, 672, 1-7 (2013). https://doi.org/10.1111/1758-2229.12066

Shi, R., Zhang, Y., Yang, W., Xu, H. Microbial community characterization of an UASB treating increased organic loading rates of vitamin $\mathrm{c}$ biosynthesis wastewater, Water Science \& Technoiogy, 65, 254-261 (2012). https://doi. org/10.2166/wst.2012.772

Singh, R., Kumar, A., Kirrolia, A., Kumar, R., Yadav, N., Bishnoi, N.R., Lohchab, R.K. Removal of sulphate, COD and $\mathrm{Cr}(\mathrm{VI})$ in simulated and real wastewater by sulphate reducing bacteria enrichment in small bioreactor and FTIR study, Bioresour Technol, 102, 677-682 (2011). https:// doi.org/10.1016/j.biortech.2010.08.041

Sicupira, D.C., Silva, T.T., Ladeira, A.C.Q., Mansur, M.B. Adsorption of manganese from acid mine drainage effluents using bone char: continuous fixed bed column and batch desorption studies. Braz. J. Chem. Eng., 32, 577-584 (2015). https:// doi.org/10.1590/0104-6632.20150322s00002681

Sun, J., Dai, X., Wang, Q., Pan, Y., Ni, B. Modelling methane production and sulfate reduction in anaerobic granular sludge reactor with ethanol as electron donor, Sci Rep, 6, 1-11 (2016). https://doi. org/10.1038/srep35312

Tsukamoto, T.K., Killion, H.A., Miller, G.C. Column experiments for microbiological treatment of acid mine drainage: low-temperature, low-pH and matrix investigations, Water Res, 38, 1405-1418 (2004). https://doi.org/10.1016/j.watres.2003.12.012

Thompson, M., Ellison, S.L.R., Wood, R., Harmonized guidelines for single-laboratory validation of methods of analysis, Pure Appl. Chem., 74, 835-855 (2002). https://doi.org/10.1351/pac200274050835

Vainshtein, M., Kuschk, P., Mattusch, J., Vatsourina, A., Wiessner, A., Model experiments on the microbial removal of chromium from contaminated groundwater, Water Res, 37, 1401-1405 (2003). https://doi.org/10.1016/S0043-1354(02)00455-4

Verma, A., Dua, R., Singh, A., Bishnoi, N.R. Biogenic sulfides for sequestration of $\mathrm{Cr}(\mathrm{VI}), \mathrm{COD}$ and sulfate from synthetic wastewater, Water Sci., 29, 19-25 (2015). https://doi.org/10.1016/j. wsj.2015.03.001

Vilela, R.S., Damianovic, M.H.R., Foresti, E. Removing organic matter from sulfate-rich wastewater via sulfidogenic and methanogenic pathways, Water Science \& Technology, 69, 16691675 (2014). https://doi.org/10.2166/wst.2014.066

Vitor, G., Palma, T.C., Vieira, B., Lourenço, J.P., Barros, R.J., Costa, M.C. Start-up, adjustment and long-term performance of a two-stage bioremediation process, treating real acid mine drainage, coupled with biosynthesis of $\mathrm{ZnS}$ nanoparticles and $\mathrm{ZnS} / \mathrm{TiO}_{2}$ nanocomposites, Miner. Eng., 75, 85-93 (2015). https://doi.org/10.1016/j.mineng.2014.12.003

Wolicka, D., Borkowski, A., Jankiewicz, U., Stępień, W., Kowalczyk, P. Biologically-induced precipitation of minerals in a medium with zinc under sulfate-reducing conditions, Polish J Microbiol, 64, 149-155 (2015).

Wu, W.-M., Hickey, R.F., Zeikus, J.G. Characterization of metabolic performance of methanogenic granules treating brewery wastewater: role of sulfate-reducing bacteria, Appl Environ Microbiol, 57, 3438-3449 (1991).

Yuan, Y., Chen, C., Zhao, Y., Wang, A., Sun, D., Huang, C., Liang, B., Tan, W., Xu, X., Zhou, X., Lee, D., Ren, D. Influence of COD/sulfate ratios on the integrated reactor system for simultaneous removal of carbon, sulfur and nitrogen, Water Science \& Technology, 71, 709-716 (2015). https:// doi.org/10.2166/wst.2014.533

Zhang, W., Wang, H. Preparation of immobilized sulfate reducing bacteria (SRB) granules for effective bioremediation of acid mine drainage and bacterial community analysis, Miner Eng, 92, 63-71 (2016). https://doi.org/10.1016/j.mineng.2016.02.008

Zhao, C., Yang, Q., Chen, W., Li, H., Zhang, H. Isolation of a sulfate reducing bacterium and its application in sulfate removal from tannery wastewater, College African Journal of Biotechnology, 10, 11966-11971 (2011). 
Zhao, J., Fang, D., Zhang, P., Zhou, L. Long-term effects of increasing acidity on low-pH sulfatereducing bioprocess and bacterial community, Environmental Science and Pollution Research, 24, 4067-4076 (2016). https://doi.org/10.1007/s11356$016-8147-2$
Zhou, J., Zhou, X., Li, Y., Xing, J. Bacterial communities in haloalkaliphilic sulfate-reducing bioreactors under different electron donors revealed by $16 \mathrm{~S}$ rRNA MiSeq sequencing, J Hazard Mater, 295, 176-184 (2015). https://doi.org/10.1016/j. jhazmat.2015.04.010 
